\title{
Responses of wetland graminoids to the relative supply of nitrogen and phosphorus
}

\section{Journal Article}

Author(s):

Güsewell, Sabine

Publication date:

2005-02

Permanent link:

https://doi.org/10.3929/ethz-b-000033789

Rights / license:

In Copyright - Non-Commercial Use Permitted

Originally published in:

Plant Ecology 176(1), https://doi.org/10.1007/s11258-004-0010-8 


\title{
Responses of wetland graminoids to the relative supply of nitrogen and phosphorus
}

\author{
Sabine Güsewell \\ Utrecht University, Department of Geobiology, P.O. Box 80084, NL-3508 TB Utrecht; and Geobotanisches \\ Institut ETH, Zürichbergstrasse 38, CH-8044 Zürich; (Tel. ++41-1-632 43 07; Fax. ++41-1-632 12 15; \\ e-mail: guesewell@env.ethz.ch)
}

Received 3 May 2002; accepted in revised form 20 January 2004

Key words: biomass allocation, Carex, growth experiment, light intensity, N:P ratio, nutrient limitation, nutrient uptake, tissue nutrient concentrations

\begin{abstract}
The biomass production of wetland vegetation can be limited by nitrogen or phosphorus. Some species are most abundant in N-limited vegetation, and others in P-limited vegetation, possibly because growth-related traits of these species respond differently to $\mathrm{N}$ versus $\mathrm{P}$ supply. Two growth experiments were carried out to examine how various morphological and physiological traits respond to the relative supply of $\mathrm{N}$ and $\mathrm{P}$, and whether species from sites with contrasting nutrient availability respond differently. In experiment 1, four Carex species were grown in nutrient solutions at five N:P supply ratios $(1.7,5,15,45,135)$ combined with two levels of supply (geometric means of $\mathrm{N}$ and $\mathrm{P}$ supply). In experiment 2, two Carex and two grass species were grown in sand at the same five N:P supply ratios combined with three levels of supply and two light intensities (45\% or 5\% daylight). After 12-13 weeks of growth, plant biomass, allocation, leaf area, tissue nutrient concentrations and rates and nutrient uptake depended significantly on the $\mathrm{N}: \mathrm{P}$ supply ratio, but the type and strength of the responses differed among these traits. The $\mathrm{P}$ concentration and the N:P ratio of shoots and roots as well as the rates of $\mathrm{N}$ and $\mathrm{P}$ uptake were mainly determined by the $\mathrm{N}: \mathrm{P}$ supply ratio; they showed little or no dependence on the supply level and relatively small interspecific variation. By contrast, the $\mathrm{N}$ concentration, root mass ratio, leaf dry matter content and specific leaf area were only weakly related to the N:P supply ratio; they mainly depended on plant species and light, and partly on overall nutrient supply. Plant biomass was determined by all factors together. Within a level of light and nutrient supply, biomass was generally maximal (i.e. co-limited by $\mathrm{N}$ and $\mathrm{P}$ ) at a $\mathrm{N}: \mathrm{P}$ supply ratio of 15 or 45 . All species responded in a similar way to the N:P supply ratio. In particular, the grass species Phalaris arundinacea and Molinia caerulea showed no differences in response that could clearly explain why $P$. arundinacea tends to invade P-rich (N-limited) sites, and M. caerulea P-limited sites. This may be due to the short duration of the experiments, which investigated growth and nutrient acquisition but not nutrient conservation.
\end{abstract}

\section{Introduction}

Plastic responses of plants to differences in nutrient supply may determine the ability of species to grow and compete successfully under various nutrient regimes (Robinson and Rorison 1988; Tilman and Wedin 1991; Reynolds and D’Antonio 1996; Garnier
1998). At low nutrient supply, plants do not only grow more slowly that at high nutrient supply but also increase their biomass allocation to roots (Poorter and Nagel 2000) and reduce the nutrient concentrations of their biomass (Aerts and Chapin 2000); various further morphological and physiological adjustments can enable plants to enhance their nutrient acquisition 
(Anuradha and Narayanan 1991; Schachtman et al. 1998; Lipson and Näsholm 2001; Tuomi et al. 2001) or to minimise their nutrient losses (Northup et al. 1998; Eckstein et al. 1999; El-Kahloun et al. 2000; Bausenwein et al. 2001). At high nutrient supply, the opposite phenotypic responses enable the plants to improve their carbon gain and to compete more effectively against other plants when light becomes limiting (Garnier 1998; Hirose and Bazzaz 1998; Schieving and Poorter 1999; Poorter and Nagel 2000).

The same type of phenotypic plasticity has been observed in response to nitrogen $(\mathrm{N})$ supply under $\mathrm{N}$ limited conditions and in response to phosphorus $(\mathrm{P})$ supply under P-limited conditions (Wilson 1988; Ingestad and Ågren 1991; Ericsson 1995; Ryser et al. 1997). This similarity of effects suggests that some plant traits respond to nutrient supply (i.e. fertility) in a general way, rather than specifically to the supply of either $\mathrm{N}$ or P. For such traits, the effect of a high supply of $\mathrm{N}$ could be (partly) negated by a low supply of $\mathrm{P}$ and vice-versa. However, strong effects of increased $\mathrm{N}$ supply on plant traits have also been found at P-poor sites (e.g. Falkengren-Grerup 1998; Flückiger and Braun 1998), and in some cases plants even responded to increased $\mathrm{N}$ and $\mathrm{P}$ supply in opposite ways (e.g. Treseder and Vitousek 2001; Güsewell et al. 2003), suggesting that the responses were specifically determined by the supply of $\mathrm{N}$ or $\mathrm{P}$ or by the supply of one relative to the other. This may be because the supply of $\mathrm{N}$ relative to that of $\mathrm{P}(\mathrm{N}: \mathrm{P}$ supply ratio) determines which of the two nutrients limits plant growth (Güsewell and Koerselman 2002), and there may be functional differences between $\mathrm{N}$ - and P-limited plants (Aerts and Chapin 2000).

There are many indications that not only changes in productivity but also shifts in the relative supplies of $\mathrm{N}$ and $\mathrm{P}$ cause changes in plant performance and in the species composition of plant communities (e.g. Verhoeven et al. 1996; Bobbink et al 1998; Roem and Berendse 2000; Willby et al 2001). Some species appear to be most successful at high $\mathrm{N}: \mathrm{P}$ supply ratios (e.g. Molinia caerulea; Kirkham 2001; Tomassen et al. 2003), and others at low N:P supply ratios (e.g. Typha $\times$ glauca; Woo and Zedler 2002), suggesting that these species respond differently (in terms of biomass production, morphology and/or physiology) to the relative supplies of $\mathrm{N}$ and $\mathrm{P}$. If we know how $\mathrm{N}: \mathrm{P}$ supply ratios affect the growth and functional traits of species that dominate at $\mathrm{N}$ - or P-limited sites, this may help us to understand and predict how changes in the relative supplies of $\mathrm{N}$ and $\mathrm{P}$ (e.g. due to atmospheric $\mathrm{N}$ deposition) will affect plant communities (Roem et al. 2002; Limpens et al. 2003).

Despite the numerous experiments investigating the plastic responses of plants to different nutrient supplies, the role of the N:P supply ratio in determining these responses has rarely been considered explicitly. Only few studies in plant ecology have varied the supplies of $\mathrm{N}$ and $\mathrm{P}$ independently from each other (e.g. Shaver and Melillo 1984; Ryser and Lambers 1995; Romero et al. 1999; Güsewell et al. 2003). As a result, we know little about the morphological and physiological traits that are decisive for the ability of plants to grow and compete under N- or P-limited conditions (but see de Kroon and Bobbink 1997; El-Kahloun et al. 2000).

The purpose of this study was to investigate how variation in the N:P supply ratio affects plant growth, biomass allocation, leaf structure, tissue $\mathrm{N}$ or $\mathrm{P}$ concentrations, and rates of $\mathrm{N}$ or $\mathrm{P}$ uptake, and to compare these effects to those of variation in overall nutrient ( $\mathrm{N}$ and $\mathrm{P}$ ) supply, all this for seven graminoid species from wetlands with contrasting productivity and nutrient limitation. I expected that morphological traits would mainly depend on overall nutrient supply, reflecting similar responses of these traits to $\mathrm{N}$ and $\mathrm{P}$ supply, whereas physiological traits related specifically to $\mathrm{N}$ or $\mathrm{P}$ use by plants should depend more on the N:P supply ratio. I further expected that species from differently productive sites would respond differently to overall nutrient supply, whereas species from $\mathrm{N}$ - and P-limited sites would respond differently to N:P supply ratios. These hypotheses were tested in two experiments involving differing growth conditions (substrates, light intensity) to assess whether the responses of plants to N:P supply ratios are consistent across growth conditions.

\section{Methods}

\section{Plant material}

The species used for the two experiments are herbaceous perennials from various types of wetland vegetation (Table 1). Experiment 1 included four Carex species that occur in sites with contrasting fertility but similar N:P ratios (Table 1a). Plants were collected in the field $(C$. curta in a floating fen, $C$. disticha in a disturbed marsh) or cultivated from seeds (C. elata, C. flava) in spring 1988, and grown outdoors in pots 
Table 1. Species included in the experiments (nomenclature: Lauber and Wagner 1996) with their main habitat (type of plant community) according to Ellenberg (1996), their indicator value for nutrients (Ellenberg et al. 1991) and their mean biomass N:P ratio in the field (Güsewell and Koerselman 2002).

\begin{tabular}{|c|c|c|c|}
\hline & Community type & $\mathrm{N}$-value ${ }^{1}$ & $\mathrm{~N}: \mathrm{P}$ ratio \\
\hline \multicolumn{4}{|l|}{ Experiment 1} \\
\hline Carex curta & Base-poor fens & 2 & 12.6 \\
\hline Carex disticha & Eutrophic fens & 5 & 13.9 \\
\hline Carex elata & Eutrophic fens & 5 & 13.8 \\
\hline Carex flava & Base-rich fens & 2 & 14.4 \\
\hline \multicolumn{4}{|l|}{ Experiment 2} \\
\hline Carex flava & Base-rich fens & 2 & 14.4 \\
\hline Carex panicea & Base-rich fens & 4 & 16.9 \\
\hline Molinia caerulea & Moist meadows, heaths & 1 & 20.0 \\
\hline Phalaris arundinacea & Eutrophic marshes & 7 & 9.2 \\
\hline
\end{tabular}

${ }^{1}$ Indicates the nutrient availability at typical sites of a species on a scale from 1 (= low) to 9 (= high)

with garden mould. In April 1999, clones were split into individual ramets (each with 2-3 leaves) and kept on tap water until new roots started to developed (approximately three weeks). Each ramet was then placed in an individual beaker, and beakers were randomly allocated to the experimental treatments. After a few days, shoots were trimmed to a length of $4 \mathrm{~cm}$ to reduce a possible influence of differences in initial size.

Experiment 2 included two Carex and two grass species. One grass, Molinia caerulea, occurs mainly at nutrient-poor, P-limited sites (low nutrient indicator value, high mean $\mathrm{N}: \mathrm{P}$ ratio), and the other grass, Phalaris arundinacea mainly at productive, P-rich sites (high nutrient indicator value, low mean N:P ratio); the two Carex species (C. flava, C. panicea) are intermediate (Table $1 \mathrm{~b}$ ). Cuttings of $C$. panicea and $M$. caerulea were collected in a fen meadow near Zürich (CH) in early May 1998, three weeks before the beginning of the experiment. After removing dead leaves, rhizomes and old roots, individual ramets were kept on tap water so that new roots could develop. Seeds of $S$. flava and $P$. arundinacea were germinated in February 1998 on filter paper; after germination seedlings were cultivated in nutrientpoor horticultural mould in the greenhouse. At planting time, seedlings and cuttings had similar size (2-3 leaves). To further reduce differences in initial size, all shoots were trimmed to a length of $4 \mathrm{~cm}$ one week after planting.

\section{Treatments}

Nutrient treatments combined five N:P supply ratios with two or three levels of overall nutrient supply in a factorial design. Nutrient supply levels were defined by the geometric mean of the amounts of $\mathrm{N}$ and $\mathrm{P}$ (in $\mathrm{mg}$ ) supplied per plant over the whole growth period. The geometric mean, rather than the arithmetic mean, was taken as measure because I expected the effects of $\mathrm{N}$ and $\mathrm{P}$ supply on plant growth to be multiplicative rather than additive. In experiment 1 , with two supply levels, the geometric means of $\mathrm{N}$ and $\mathrm{P}$ supply per plant were $3.9 \mathrm{mg}$ (= low supply) and 11.6 $\mathrm{mg}$ (= high supply); in experiment 2 , with three supply levels, these means were $2.58 \mathrm{mg}$ (= low supply), $7.75 \mathrm{mg}$ (= medium supply) and $23.24 \mathrm{mg}$ (= high supply). Within each supply level, the average N:P ratio was set to 15 , the $\mathrm{N}: \mathrm{P}$ ratio at which plants were likely to be equally limited by $\mathrm{N}$ and $\mathrm{P}$ (Koerselman and Meuleman 1996). Five different N:P supply ratios differing by a factor of three $(1.7,5,15,45$ and 135) were obtained by multiplying $\mathrm{N}$ supply and dividing P supply by $0.33,0.58,1,1.73$ and 3 , respectively. The resulting amounts of $\mathrm{N}$ and $\mathrm{P}$ are given in Table 2.

Nutrients were supplied once or twice weekly, $\mathrm{N}$ as $\mathrm{KNO}_{3}$, and $\mathrm{P}$ as $\mathrm{KH}_{2} \mathrm{PO}_{4}$. All other essential nutrients were supplied in constant, non-limiting amounts, based on $\mathrm{N}$ supply at the high supply level with $\mathrm{N}: \mathrm{P}$ ratio 15 and the composition of Hoagland nutrient solutions. For potassium, part of this amount was provided by the compounds used to supply $\mathrm{N}$ and $\mathrm{P}$, and the rest by adding $\mathrm{KCl}$. The weekly supply of nutrients was increased over the course of the growth period to be three times greater in the last third than in the first third of the experiment, in order to avoid plants being much more nutrient-limited at the end of the growth period due to their greater size. 
Table 2. Total amounts of nitrogen and phosphorus supplied to each plant in the course of the growth experiments. Treatments combined five $\mathrm{N}: \mathrm{P}$ supply ratios with two or three levels of nutrient supply ('high', 'medium', 'low').

\begin{tabular}{|c|c|c|c|c|c|c|c|c|c|c|}
\hline \multirow[b]{3}{*}{$\mathrm{N}: \mathrm{P}$ ratio } & \multicolumn{5}{|c|}{$\mathrm{N}$ supply (mg plant $\left.{ }^{-1}\right)$} & \multicolumn{5}{|c|}{$\mathrm{P}$ supply (mg plant $\left.{ }^{-1}\right)$} \\
\hline & \multicolumn{2}{|c|}{ Experiment 1} & \multicolumn{3}{|c|}{ Experiment 2} & \multicolumn{2}{|c|}{ Experiment 1} & \multicolumn{3}{|c|}{ Experiment 2} \\
\hline & High & Low & High & Medium & Low & High & Low & High & Medium & Low \\
\hline 1.7 & 15.0 & 5.0 & 30.0 & 10.0 & 3.3 & 9.0 & 3.0 & 18.0 & 6.0 & 2.0 \\
\hline 5 & 26.0 & 8.7 & 52.0 & 17.3 & 5.8 & 5.2 & 1.7 & 10.4 & 3.5 & 1.2 \\
\hline 15 & 45.0 & 15.0 & 90.0 & 30.0 & 10.0 & 3.0 & 1.0 & 6.0 & 2.0 & 0.7 \\
\hline 45 & 78.0 & 26.0 & 156.0 & 52.0 & 17.3 & 1.7 & 0.6 & 3.5 & 1.2 & 0.4 \\
\hline 135 & 135.0 & 45.0 & 270.0 & 90.0 & 30.0 & 1.0 & 0.3 & 2.0 & 0.7 & 0.2 \\
\hline
\end{tabular}

\section{Growth conditions}

Experiment 1 took place in an open greenhouse in Zürich, with approximately 50\% daylight, between May and July 1999. Plants were grown in nutrient solutions in $0.25-1$ beakers. Beakers were covered with a black foam lid and wrapped in aluminium foil so as to be dark inside. One shoot per beaker was inserted in a slide made on one side of the lid, so that the shoot base was at the lid surface and roots hung into the nutrient solution. Six plants per species were randomly allocated to each of the ten nutrient treatments (five N:P supply ratios, two overall supply levels). Nutrient solutions were replaced completely every two weeks. At each time, beakers received 160 $\mathrm{ml}$ of a new solution containing the appropriate concentrations of $\mathrm{KNO}_{3}, \mathrm{KH}_{2} \mathrm{PO}_{4}$ and $\mathrm{KCl}$ as well as all other essential elements. In addition, $\mathrm{N}, \mathrm{P}$ and $\mathrm{K}$ were supplied twice weekly by adding $2 \mathrm{ml}$ of nutrient solution to each beaker; evaporated water was replaced simultaneously. Beakers were not aerated, but water movement was caused regularly by adding nutrient solution, adding water or moving plants within the greenhouse (to reduce effects of spatial variation), which likely reduced the depletion of nutrients around roots. At the end of the experiment, the largest plants had completely filled the beakers with their roots and may have been limited in their growth by beaker size, but since this only concerned a few plants grown at the optimal nutrient treatments, it is unlikely that beaker size significantly affected the results.

Experiment 2 took place in the garden of the Geobotanical Institute ETH in Zürich between June and August 1998. Individual shoots of the four graminoid species were planted in pots $(9 \mathrm{~cm}$ diameter) with quartz sand in May 1998. Four plants per species were randomly attributed to each of the 15 nutrient treatments (five N:P supply ratios, three overall sup- ply levels). Two plants per species and treatment grew at $45 \%$ and at $5 \%$ daylight, respectively, which is comparable to light regimes of 300 and $33 \mu \mathrm{mol} \mathrm{m}{ }^{-2}$ $\mathrm{s}^{-1}$ during $16 \mathrm{~h}$ per day. Light was regulated with green horticultural shading cloth (ST30, HORTIMA, Hausen, Switzerland) fixed on wooden frames, both on the top and at the sides, but leaving an open space of approximately $50 \mathrm{~cm}$ height above ground to allow free air circulation around the pots. Two shade houses were constructed per light level. Transparent plastic foil was spanned approximately $30 \mathrm{~cm}$ above the shading cloth to protect pots against rainwater. Pots were placed on trays and watered by adding deionised water to the trays. Nutrients were supplied weekly by giving each plant $2 \mathrm{ml}$ of a solution with appropriate concentrations of $\mathrm{KNO}_{3}, \mathrm{KH}_{2} \mathrm{PO}_{4}$ and $\mathrm{KCl}$. To prevent a toxic accumulation of nutrients not taken up by plants, pots were leached with deionised water every two weeks, at least four days after the last fertilisation. Treatments lasted for 12 weeks, the last fertilisation being five days before harvest.

\section{Measurements of nutrient uptake}

Three replicates of each species and treatment in experiment 1 were used for measurements of nutrient uptake. After 13 weeks of cultivation plants were taken out of their beakers together with the lids. Roots were rinsed with deionised water, after which plants were placed into clean breakers filled with deionised water. One day later, plants were placed in new beakers containing $170 \mathrm{ml}$ of a standard nutrient solution whose $\mathrm{N}$ and $\mathrm{P}$ concentrations $\left(6 \mathrm{mg} \mathrm{N}^{-1}, 0.34 \mathrm{mg}\right.$ $\mathrm{P}^{-1}$ ) corresponded approximately to the final concentrations of the treatment with low overall supply and N:P ratio 15 . The total weight of beakers (with nutrient solutions and plants) was determined. Exactly $7 \mathrm{~h}$ later, beakers were weighed again to de- 
termine water loss. Plants were then removed, gently shaking water from roots. The remaining solution in the beakers was mixed; samples $(20 \mathrm{ml})$ were taken and stored frozen until the concentrations of nitrate, ammonium and phosphate were analysed colorimetrically on a continuous-flow analyser (Skalar SA-40, Skalar, Breda, NL). Differences in water volume and in nutrient concentrations were used to calculate what percentage of the original amounts of $\mathrm{N}$ and $\mathrm{P}$ had been taken up by plants during $7 \mathrm{~h}$.

\section{Harvest and measurements}

At harvest plants were subdivided into above-ground biomass ('shoots' = leaf blades, leaf sheaths and culms) and below-ground biomass ('roots' = rhizomes and roots). In experiment 2, the total area of leaf blades was measured on a leaf area meter, and their fresh weight was determined after several hours between wet paper tissues to obtain maximal water saturation. All harvested plant material was dried (48 $\mathrm{h}$ at $70^{\circ} \mathrm{C}$ ) and weighed. The data were used to calculate the root mass ratio (RMR, ratio of belowground biomass to total biomass), specific leaf area (SLA, ratio of leaf area to leaf dry mass) and dry matter content (DM, ratio of leaf dry mass to leaf fresh mass).

For nutrient analyses, plant material was ground in a centrifugal mill and digested with a modified Kjeldahl procedure $\left(1 \mathrm{~h}\right.$ at $200{ }^{\circ} \mathrm{C}$ and $2 \mathrm{~h}$ at $340{ }^{\circ} \mathrm{C}$ in a mixture of concentrated sulphuric acid, salicylic acid, copper and selenium). Concentrations of $\mathrm{N}$ and $\mathrm{P}$ in the digests were analysed colorimetrically on a continuous-flow analyser (Skalar SA-40, Skalar, Breda, NL). Only three replicates of each species and treatment were analysed in experiment 1, discarding plants that had been used for nutrient uptake measurements.

\section{Data analysis}

Responses to nutrient treatments were analysed statistically using analysis of variance, graphically by plotting treatment means against the N:P supply ratio, and finally, by calculating norms of reaction for the plastic responses of each species to treatments. The purpose of the statistical analysis was to compare and to test the effects of the N:P supply ratio, the overall level of nutrient supply and their interaction as well as of interspecific differences. Experiment 1 was analysed with a three-way full-factorial ANOVA (main factors $=\mathrm{N}: \mathrm{P}$ supply ratio, overall level, species, all fixed factors). Experiment 2 had a split-plot design with light intensity as main-plot factor and nutrient treatments and species as subplot factors. Because the responses to nutrient supply differed considerably between $45 \%$ and $5 \%$ light intensity, data were analysed for the two light levels separately, treating shade houses as blocks (fixed factor). All calculations were carried out with the statistical software JMP, Version 3.2.2 (SAS Institute 1989-1997).

The purpose of the graphical analysis was to visualise whether plant traits were determined by an individual nutrient ( $\mathrm{N}$ or $\mathrm{P}$ ), the $\mathrm{N}: \mathrm{P}$ supply ratio, the overall level of nutrient supply, the limiting nutrient or the (un)balance of nutrient supply. These various options are shown with fictive data in Figure 1. Each graph in Figure 1 represents measurements of a hypothetical plant trait for the 15 nutrient treatments of experiment 2 (five $\mathrm{N}: \mathrm{P}$ supply ratios on the $\mathrm{X}$-axis, three level of overall supply represented by different symbols). Figure 1a represents a plant trait entirely determined by the supply of nitrogen. Measurements increase with increasing $\mathrm{N}: \mathrm{P}$ supply ratio, and all pairs of treatments with the same supply of $\mathrm{N}$ (cf. Table 1) have the same values for the trait (horizontal dashed lines; only shown for some of the pairs). By contrast, treatments with the same supply of $\mathrm{P}$ can have strongly different values for the trait (one dotted line shown as example). Figure $1 \mathrm{~b}$ represents a plant trait entirely determined by the supply of phosphorus; patterns are exactly opposite to those in Figure 1a, i.e. the same supply of $\mathrm{P}$ results in the same values for the trait (horizontal dotted lines). A linear relationship is arbitrarily shown in 1a, and a non-linear relationship in $1 \mathrm{~b}$, but both may occur with either type of limitation. In Figure 1c, the plant trait is entirely determined by the N:P supply ratio, being independent of overall nutrient supply. High and low N:P ratios are associated with contrasting values for this trait, and measurements are intermediate when the supply of $\mathrm{N}$ and $\mathrm{P}$ is balanced. In Figure 1d, the plant trait is entirely determined by overall nutrient supply, being independent of the N:P supply ratio. This situation would arise if $\mathrm{N}$ supply and $\mathrm{P}$ supply influence the trait in exactly the same way, so that the effects of increasing one nutrient and decreasing the other compensate each other. Both in $1 \mathrm{c}$ and in $1 \mathrm{~d}$, pairs of treatments with the same supply of $\mathrm{N}$ or $\mathrm{P}$ always differ for the plant trait considered. Figure 1e represents the situation where the trait is determined by $\mathrm{N}$ supply or by $\mathrm{P}$ supply depending on the N:P supply 


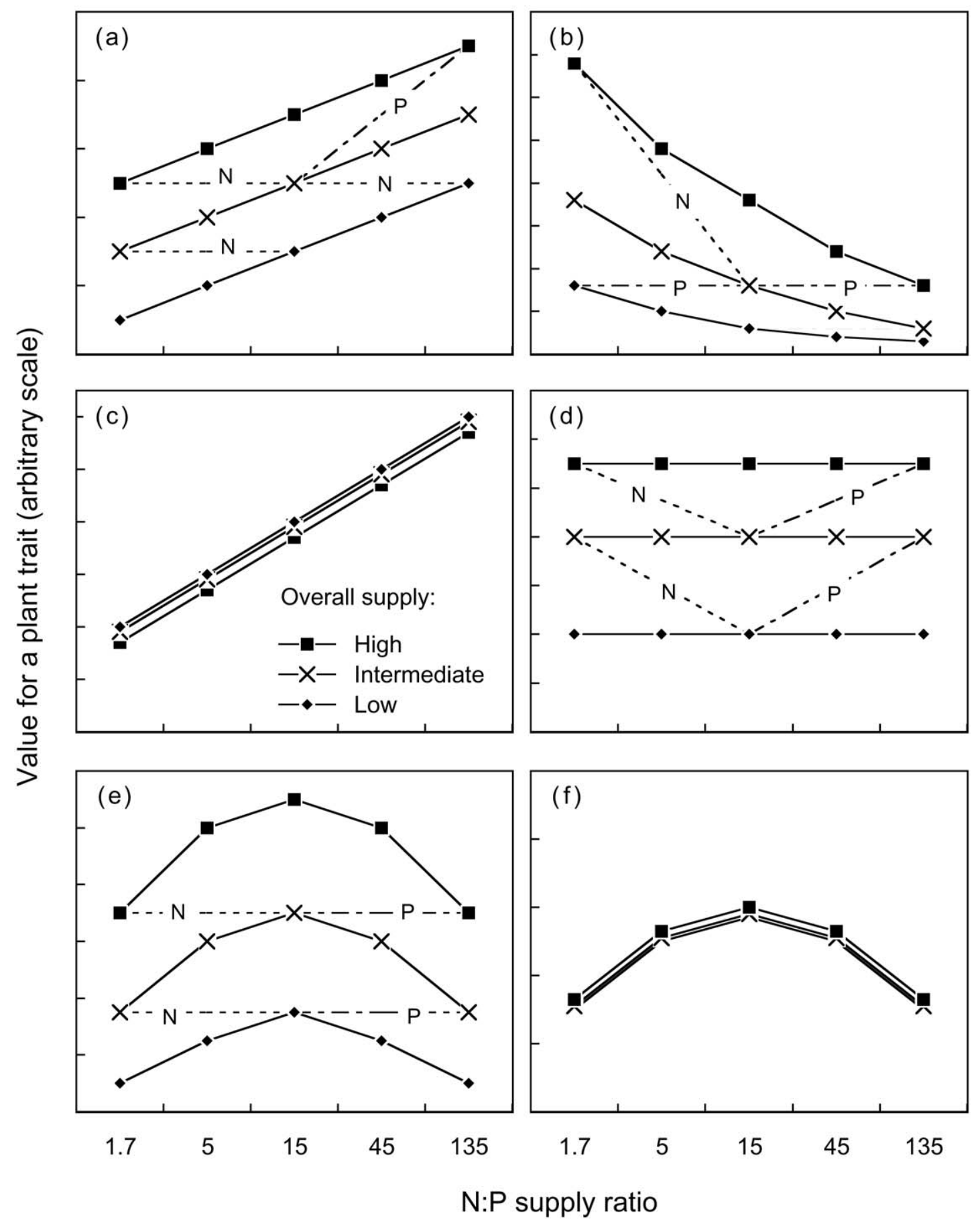

Figure 1. Theoretical relationships between a plant trait and the N:P supply ratio, for plant traits determined by (a) the supply of nitrogen (N-limited), (b) the supply of phosphorus (P-limited), (c) the N:P supply ratio, (d) overall nutrient supply, (e) N or P, depending on the N:P supply ratio, and (f) the degree of balance in nutrient supply. Each symbol in the graphs represents one of the 15 nutrient treatments of experiment 2 . The five $\mathrm{N}: \mathrm{P}$ supply ratios are plotted on the $\mathrm{x}$-axis, and the three levels of overall supply are visualised by different symbols. Where appropriate, dashed or dotted lines show examples of pairs of treatments receiving the same supply of $\mathrm{N}$ (dashed) or P (dotted). 
ratio, with a threshold around $\mathrm{N}: \mathrm{P}=15$. Below this threshold (N-limitation), similar values of the trait are obtained for pairs of treatments with the same N-supply, and above this threshold (P-limitation) similar values are obtained with the P-supply. Finally, Figure 1f represents the situation where the trait is determined by the balance or unbalance of nutrient supply: its value is reduced when the N:P supply ratio is above or below 15, regardless of overall supply. The six situations represented in Figure 1 are theoretical extremes, and any intermediate or combination of them may occur in practice.

Two graphs are presented for each variable: one showing how the effects of the N:P supply ratio depend on overall nutrient supply (treatment means across species), and one showing how each species responds to the $\mathrm{N}: \mathrm{P}$ supply ratio (averaged across supply levels, at $45 \%$ light in experiment 2). This simplified representation adequately shows the effects of treatments because the three-way interactions (species $\times \mathrm{N}: \mathrm{P}$ ratio $\times$ supply level) were always weak and in most cases not significant. Full data are available from the author on request.

To quantify and compare the plasticity of plants in response to the three main experimental factors $(\mathrm{N}: \mathrm{P}$ supply ratio, overall supply, light), norms of reaction of the species to each of these factors were calculated for some variables (total biomass, root mass ratio, $\mathrm{N}$ and $\mathrm{P}$ concentrations in shoots). First, least-squares means of the four variables were determined for each species and each level of the three main factors. The norm of reaction to light intensity or to overall nutrient supply was the difference between means for the high and the low level of the factor divided by the overall mean. The norm of reaction to the N:P supply ratio was the difference between the highest and the lowest of the five means, divided by the overall mean.

\section{Results}

\section{Biomass and allocation}

In experiment 1 , total biomass (above and below ground) was affected significantly by the three main factors, i.e. the N:P supply ratio, overall nutrient supply and species (Table 3). Two-way interactions were significant but of minor importance compared with main effects (cf. $F$-values in Table 3 ), i.e. relationships between total biomass and $\mathrm{N}: \mathrm{P}$ supply ratios were essentially similar for the two supply levels
Table 3. Effects of the N:P supply ratio and level of nutrient supply on total biomass (log-transformed) and root mass ratio (RMR) of four Carex species in experiment 1 . Figures are $F$-ratios and levels of significance from three-way ANOVA. $* * *=P<0.001$; $* *=$ $P<0.01, *=P<0.05{ }^{*}{ }^{\text {ns }}=P \geq 0.05$.

\begin{tabular}{lrcc}
\hline & df & Biomass & \multicolumn{1}{c}{ RMR } \\
\hline N:P supply & 4 & $38.8 * * *$ & $8.4 * * *$ \\
Supply level & 1 & $333.2 * * *$ & $59.0 * * *$ \\
Species & 3 & $86.1 * * *$ & $35.2 * * *$ \\
N:P $\times$ supply level & 4 & $2.1 n s$ & $0.7^{\mathrm{ns}}$ \\
$\mathrm{N}: \mathrm{P} \times$ species & 12 & $2.6 * *$ & $0.7^{\mathrm{ns}}$ \\
Supply level $\times$ species & 3 & $4.4^{* *}$ & $3.2 *$ \\
$\mathrm{~N}: \mathrm{P} \times$ level $\times$ species & 12 & $1.1^{\mathrm{ns}}$ & $0.4^{\mathrm{ns}}$
\end{tabular}

(Figure 2a) and for the four species (Figure 2b). Some differences were nevertheless apparent: biomass was greatest at a N:P supply ratio of 15 with the high supply level but 45 with the low supply level (Figure 2a), and $C$. curta was reduced more severely at $\mathrm{N}: \mathrm{P}=135$ than the three other species (Figure 2b).

The root mass ratio (RMR) was also affected significantly by the three main factors, but these effects were less pronounced than for biomass (smaller $F$-values in Table 3). Again, the effects of N:P ratios were largely consistent across species and supply levels, i.e. the RMR was always maximal at $\mathrm{N}: \mathrm{P}=$ 1.7, and generally minimal at $\mathrm{N}: \mathrm{P}=45$ (Figure 2c, d). At all N:P supply ratios, the RMR was greater at the low supply level than at the high one (Figure 2c); the species with the greatest allocation to roots was always $C$. elata, which also had the greatest total biomass, and the species with the smallest allocation to roots was C. flava (Figure 2d).

In experiment 2, the total biomass of plants differed considerably between $45 \%$ and $5 \%$ daylight (Figure 3a). Within each light level, biomass depended significantly on the N:P supply ratio, overall nutrient supply and species, but the importance of these factors differed: at $45 \%$ daylight, overall nutrient supply had the strongest effect on biomass, whereas at $5 \%$ daylight, differences were mainly among species (Table 4). At 45\% daylight, overall nutrient supply also determined how total biomass was related to the $\mathrm{N}$ :P supply ratio: with high or intermediate nutrient supply, biomass was maximal at $\mathrm{N}: \mathrm{P}$ supply ratios of 15 or 45, but with low nutrient supply biomass increased up to $\mathrm{N}: \mathrm{P}=135$ (Figure 3a). Of the four species, three had their maximal biomass (averaged across supply levels) at $\mathrm{N}: \mathrm{P}=45$, with little difference between $\mathrm{N}: \mathrm{P}=45$ and 135 . In contrast, the bio- 

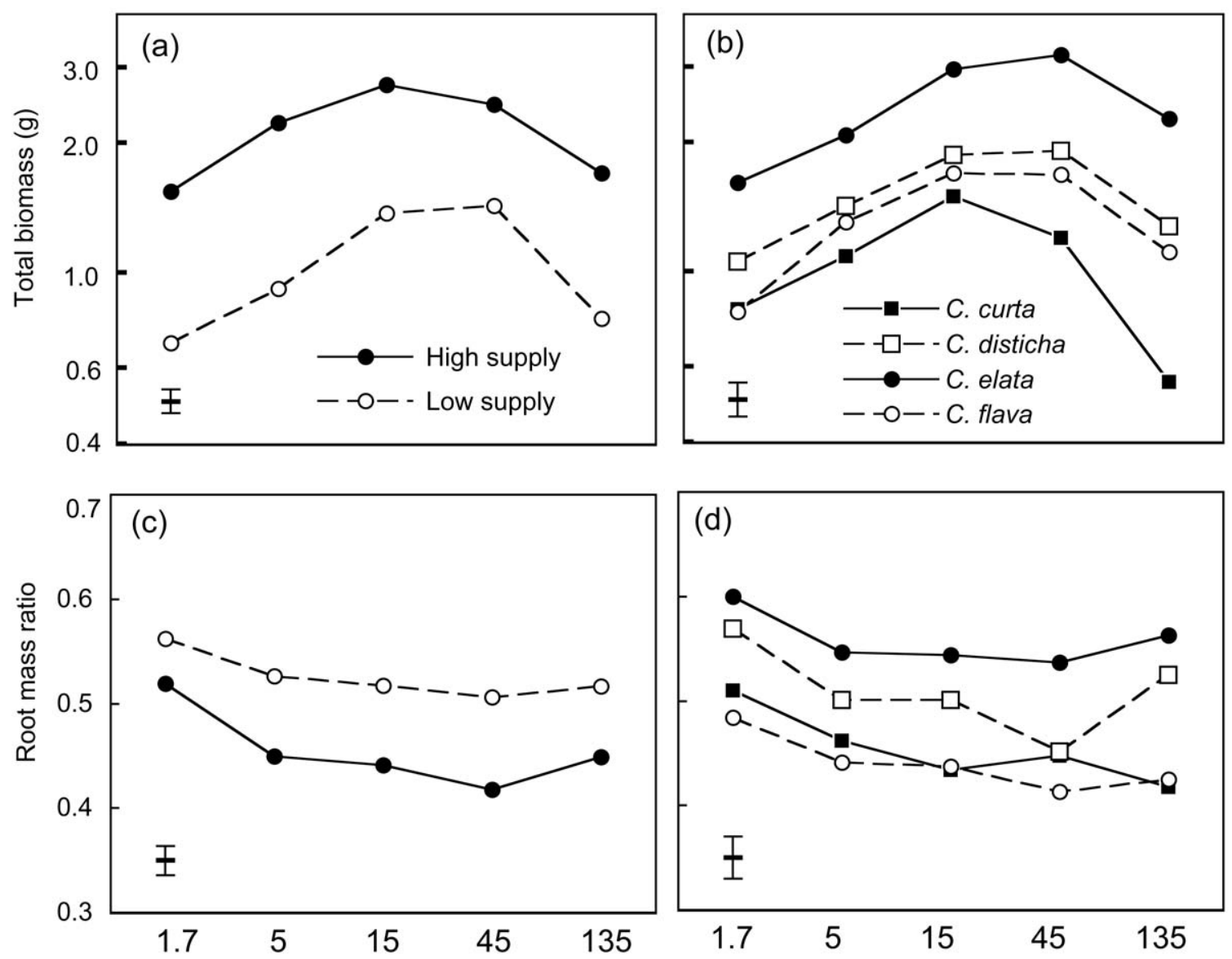

\section{$\mathrm{N}: \mathrm{P}$ supply ratio}

Figure 2. Total biomass (log scale) and roots mass ratio of four Carex species after 13 weeks of growth in nutrient solutions with five different N:P supply ratios and two levels of overall nutrient supply (experiment 1). Graphs (a) and (c) show means of the four species for each supply level; graphs (b) and (d) show means of the two supply levels for each species; error bars indicate \pm 1 SE of the means, as derived from three-way Anova.

mass of $M$. caerulea was maximal at $\mathrm{N}: \mathrm{P}=15$ and minimal at $\mathrm{N}: \mathrm{P}=135$ (Figure $3 \mathrm{~b}$ ).

More biomass was allocated to roots at $45 \%$ than at 5\% daylight (Figure 3c). Within each light level, the RMR was affected significantly by the three main factors, whereas none of the interactions was significant (Table 4). In general, the RMR decreased with increasing overall nutrient supply and with increasing $\mathrm{N}: \mathrm{P}$ ratio (Figure 3c). M. caerulea had a higher RMR than the other species, and its RMR increased at high $\mathrm{N}: \mathrm{P}$ supply ratios (Figure $3 \mathrm{~d}$ ).

The plasticity of biomass and RMR in response to the treatments varied among species (Table 5). Within species, responses to N:P supply ratios and to overall nutrient supply were similar, whereas responses to light (experiment 2) were often stronger. $P$. arundinacea was most plastic in response to nutrients and least plastic in response to light. $M$. caerulea and C. panicea were least responsive to nutrients but $M$. caerulea was most responsive to light. The RMR was greater and less plastic in $M$. caerulea than in the three other species (Table 5).

\section{Leaf structure}

Leaf structure in experiment 2 differed considerably between $45 \%$ and $5 \%$ daylight and among species (Table 4; Figure 4). The effects of N:P supply ratios were comparatively weak and not consistent. At $45 \%$ daylight, leaf dry matter content (DM) increased and 

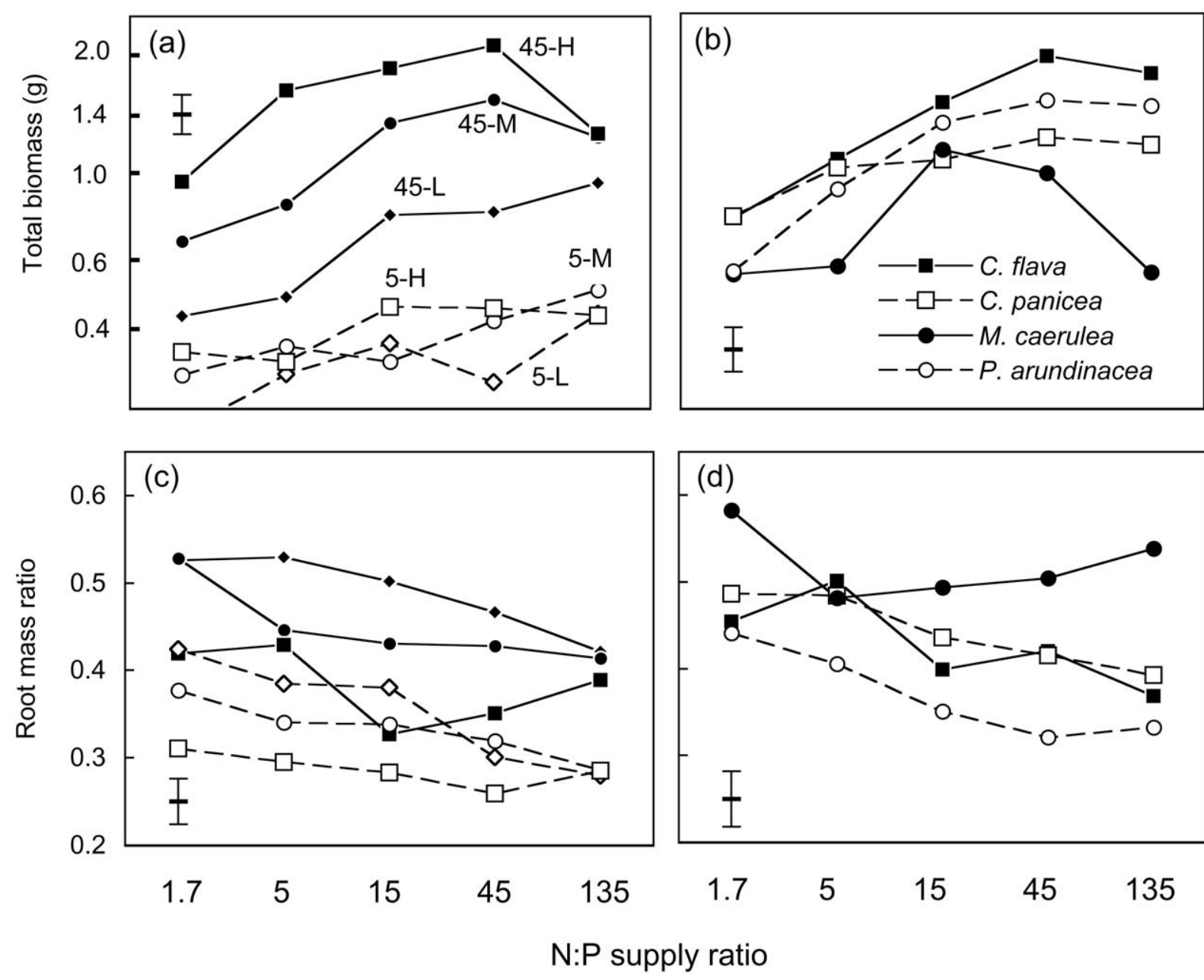

Figure 3. Total biomass (log scale) and root mass ratio of four graminoid species after 12 weeks of growth in sand (experiment 2) at five N:P supply ratios, two light intensities ( $45 \%$ or $5 \%$ daylight) and three levels of overall nutrient supply $(\mathrm{H}=\mathrm{high}, \mathrm{M}=\mathrm{medium}, \mathrm{L}=\mathrm{low})$. Graphs (a) and (c) show means of the four species for each light and supply level; graphs (b) and (d) show means of the three supply levels at $45 \%$ daylight for each species; error bars indicate $\pm 1 \mathrm{SE}$ of the means, as derived from three-way Anova.

the specific leaf area (SLA) decreased with increasing N:P supply ratio (Figure $4 \mathrm{a}, \mathrm{c}$ ). The increase in DM occurred in all species (Figure 4b), whereas the decrease in SLA was essentially limited to $P$. arundinacea (Figure 4d). At 5\% light, nutrient treatments hardly affected the leaf structure.

\section{Nutrient uptake}

The rates of $\mathrm{N}$ and $\mathrm{P}$ uptake from a standard nutrient solution at the end of experiment 1 depended primarily on the N:P supply ratio during growth; in comparison, overall nutrient supply only had a weak effect on $\mathrm{N}$ uptake and no consistent effect on $\mathrm{P}$ up- take (Table 6). Between $23 \%$ and $85 \%$ of the $\mathrm{N}$ was taken up in $7 \mathrm{~h}$ by plants grown at $\mathrm{N}: \mathrm{P}$ ratios $\leq 15$, but less than $15 \%$ of the $\mathrm{N}$ by plants grown at $\mathrm{N}: \mathrm{P}$ $\geq 45$ (Figure 5a, b). Between $50 \%$ and $92 \%$ of the $P$ was taken up by plants grown at $\mathrm{N}: \mathrm{P} \geq 5$, but less than $40 \%$ of the $\mathrm{P}$ by plants grown at $\mathrm{N}: \mathrm{P}=1.7$ (Figure $5 \mathrm{c}, \mathrm{d})$. The effects of $\mathrm{N}: \mathrm{P}$ supply ratios and of overall supply interacted significantly (Table 2): plants grown at the low supply level and low N:P ratio took up less $\mathrm{N}$ than plants grown at the high supply level, whereas supply levels did not differ at high $\mathrm{N}: \mathrm{P}$ ratios (Figure 5a); for $\mathrm{P}$ uptake the interaction had an irregular pattern (Figure 5c). The uptake rates of the four species and their responses to N:P supply 
Table 4. Effects of the N:P supply ratio and level of nutrient supply on total biomass (log-transformed), root mass ratio (RMR), leaf dry matter content (DM) and specific leaf area (SLA, log-transformed) of four wetland graminoids in experiment 2 . Data were analysed separately for plants grown at $45 \%$ and $5 \%$ daylight. Figures are $F$-ratios and levels of significance from three-way ANOVA for a block design. $* * *=P<0.001 ; * *=P<0.01, *=P<0.05 ;{ }^{\text {ns }}=\mathrm{P} \geq 0.05$.

\begin{tabular}{|c|c|c|c|c|c|}
\hline & df & Biomass & RMR & Leaf DM & SLA \\
\hline \multicolumn{6}{|l|}{$45 \%$ daylight } \\
\hline $\mathrm{N}: \mathrm{P}$ supply ratio & 4 & $25.0 * * *$ & $4.5 * *$ & $16.0 * * *$ & $11.3 * * *$ \\
\hline Supply level & 2 & $77.9 * * *$ & $15.2 * * *$ & $0.4^{\mathrm{ns}}$ & $7.7 * *$ \\
\hline Species & 3 & $22.0 * * *$ & $16.5 * * *$ & $188.4 * * *$ & $350.7 * * *$ \\
\hline $\mathrm{N}: \mathrm{P} \times$ supply level & 8 & $2.9 * *$ & $1.1^{\mathrm{ns}}$ & $2.4 *$ & $3.4 * *$ \\
\hline $\mathrm{N}: \mathrm{P} \times$ species & 12 & $2.5 * *$ & $0.9^{\mathrm{ns}}$ & $1.1^{\mathrm{ns}}$ & $2.5 *$ \\
\hline Supply level $\times$ species & 6 & $1.5^{\mathrm{ns}}$ & $0.5^{\mathrm{ns}}$ & $0.6^{\mathrm{ns}}$ & $5.6 * * *$ \\
\hline $\mathrm{N}: \mathrm{P} \times$ level $\times$ species & 24 & $1.3^{\mathrm{ns}}$ & $0.6^{\mathrm{ns}}$ & $1.5^{\mathrm{ns}}$ & \\
\hline Block & 1 & $0.1^{\mathrm{ns}}$ & $3.6^{\mathrm{ns}}$ & $4.7 *$ & $0.0^{\mathrm{ns}}$ \\
\hline \multicolumn{6}{|l|}{$5 \%$ daylight } \\
\hline $\mathrm{N}: \mathrm{P}$ supply ratio & 4 & $6.3 * * *$ & $7.5 * * *$ & $2.3^{\mathrm{ns}}$ & $1.0^{\mathrm{ns}}$ \\
\hline Supply level & 2 & $5.2 * *$ & $13.0 * * *$ & $2.6^{\mathrm{ns}}$ & $0.2^{\mathrm{ns}}$ \\
\hline Species & 3 & $52.1 * * *$ & $44.0 * * *$ & $321.4 * * *$ & $163.8 * * *$ \\
\hline $\mathrm{N}: \mathrm{P} \times$ supply level & 8 & $1.3^{\mathrm{ns}}$ & $1.3^{\mathrm{ns}}$ & $1.4^{\mathrm{ns}}$ & $0.3^{\mathrm{ns}}$ \\
\hline $\mathrm{N}: \mathrm{P} \times$ species & 12 & $1.6^{\mathrm{ns}}$ & $1.2^{\mathrm{ns}}$ & $1.8^{\mathrm{ns}}$ & $0.5^{\mathrm{ns}}$ \\
\hline Supply level $\times$ species & 6 & $2.4 *$ & $1.4^{\mathrm{ns}}$ & $0.8^{\mathrm{ns}}$ & $0.3^{\mathrm{ns}}$ \\
\hline $\mathrm{N}: \mathrm{P} \times$ level $\times$ species & 24 & $1.1^{\mathrm{ns}}$ & $0.6^{\mathrm{ns}}$ & $1.3^{\mathrm{ns}}$ & $0.5^{\mathrm{ns}}$ \\
\hline Block & 1 & $1.2^{\mathrm{ns}}$ & $19.9 * * *$ & $0.7^{\mathrm{ns}}$ & $0.1^{\mathrm{ns}}$ \\
\hline
\end{tabular}

Table 5. Plasticity of total biomass and of the root mass ratio in response to variation in the N:P supply ratio, level of nutrient supply and light intensity for each species in experiments 1 and 2. For both variables the mean across all treatments is given in the first column; plasticity (in $\%$ of the overall mean) is the relative difference between the highest and the lowest treatment mean for each of the three experimental factors.

\begin{tabular}{|c|c|c|c|c|c|c|c|c|}
\hline & \multicolumn{4}{|c|}{ Total biomass } & \multicolumn{4}{|c|}{ Root mass ratio } \\
\hline & Mean $(\mathrm{g})$ & $\mathrm{N}: \mathrm{P}$ ratio & $\begin{array}{l}\text { Supply } \\
\text { level }\end{array}$ & Light & Mean & $\mathrm{N}: \mathrm{P}$ ratio & $\begin{array}{l}\text { Supply } \\
\text { level }\end{array}$ & Light \\
\hline \multicolumn{9}{|l|}{ Experiment 1} \\
\hline Carex curta & 0.97 & 82.8 & 90.9 & & 0.45 & 20.1 & 6.9 & \\
\hline Carex disticha & 1.47 & 58.4 & 67.3 & & 0.51 & 23.1 & 19.3 & \\
\hline Carex elata & 2.35 & 67.6 & 64.8 & & 0.56 & 11.3 & 12.4 & \\
\hline Carex flava & 1.27 & 72.9 & 79.1 & & 0.44 & 16.4 & 17.2 & \\
\hline \multicolumn{9}{|l|}{ Experiment 2} \\
\hline Carex flava & 0.77 & 72.9 & 67.5 & 116.9 & 0.35 & 34.3 & 31.3 & 48.9 \\
\hline Carex panicea & 0.58 & 32.2 & 42.0 & 124.9 & 0.38 & 17.6 & 13.6 & 31.7 \\
\hline Molinia caerulea & 0.39 & 32.7 & 48.2 & 133.3 & 0.49 & 13.4 & 17.0 & 14.0 \\
\hline Phalaris arundinacea & 0.80 & 83.8 & 75.3 & 61.4 & 0.32 & 52.3 & 31.4 & 28.8 \\
\hline
\end{tabular}

ratios were similar. The main difference was that $C$. flava and $C$. disticha took up $\mathrm{N}$ faster than $C$. curta and $C$. elata when $\mathrm{N}$ was limiting (Figure 5b), but they did not take up $\mathrm{P}$ faster when $\mathrm{P}$ was limiting (Figure 5d).

\section{Nutrient concentrations and N:P ratios of plant biomass}

In both experiments, the $\mathrm{N}$ and $\mathrm{P}$ concentrations and $\mathrm{N}: \mathrm{P}$ ratios of shoots and roots depended significantly on the N:P supply ratio (Table 6; Anova results for experiment 2 were similar and are not shown). The $\mathrm{N}$ concentration varied less than two-fold across the range of $\mathrm{N}: \mathrm{P}$ supply ratios (Figure 6a-d and 7a-d), 

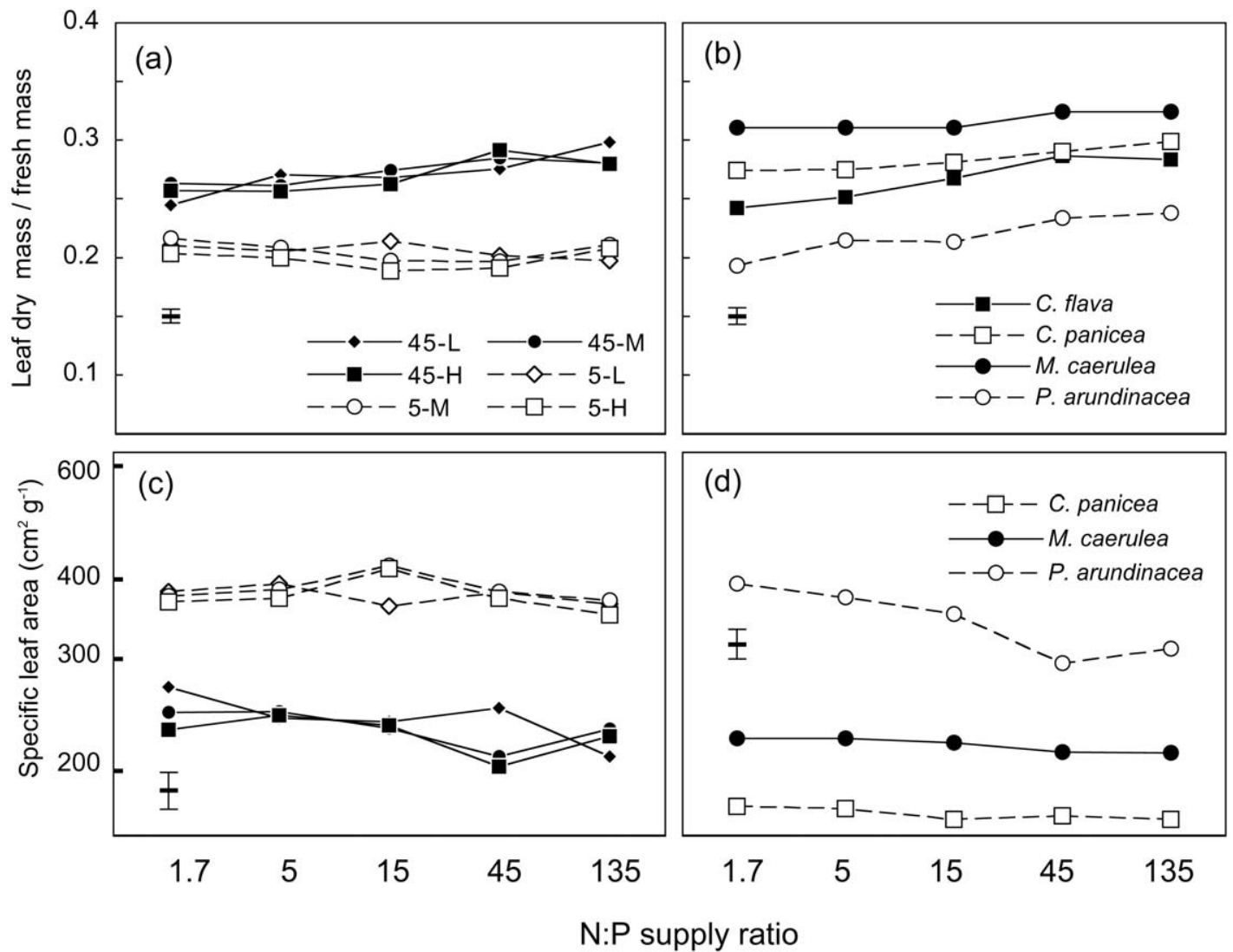

Figure 4. Leaf dry matter content and specific leaf area (log scale) of three or four graminoid species after 12 weeks of growth in sand (experiment 2) at five N:P supply ratios, two light intensities (45\% or 5\% daylight) and three levels of overall nutrient supply ( $\mathrm{H}=$ high, $\mathrm{M}$ $=$ medium, $\mathrm{L}=$ low). The SLA of $C$. flava was not determined for lack of time. Graphs (a) and (c) show means of the three or four species for each light and supply level; graphs (b) and (d) show means of the three supply levels at $45 \%$ daylight for each species; error bars indicate $\pm 1 \mathrm{SE}$ of the means, as derived from three-way Anova.

Table 6. Effects of the N:P supply ratio and level of nutrient supply on the nutrient uptake (fraction of $\mathrm{N}$ or $\mathrm{P}$ taken up in $7 \mathrm{~h}$ from a standard solution) and on the $\mathrm{N}$ and $\mathrm{P}$ concentrations and N:P ratios of shoots and roots of four Carex species in experiment 1 . Figures are $F$-ratios and levels of significance from three-way ANOVA with arcsine-transformed (nutrient uptake) or log-transformed (other variables) data. *** $=P<0.001$; ** $=P<0.01,{ }^{*}=P<0.05$; $^{\text {ns }}=P \geq 0.05$.

\begin{tabular}{|c|c|c|c|c|c|c|c|c|c|}
\hline & \multirow[b]{2}{*}{ df } & \multicolumn{2}{|c|}{ Nutrient uptake } & \multicolumn{2}{|c|}{$\mathrm{N}$ concentration } & \multicolumn{2}{|c|}{$\mathrm{P}$ concentration } & \multicolumn{2}{|l|}{$\mathrm{N}: \mathrm{P}$ ratio } \\
\hline & & $\mathrm{N}$ & $\mathrm{P}$ & Shoot & Root & Shoot & Root & Shoot & Root \\
\hline $\mathrm{N}: \mathrm{P}$ supply ratio & 4 & $84.4 * * *$ & $100.2 * * *$ & $12.4 * * *$ & $25.7 * * *$ & $408.8 * * *$ & $264.4 * * *$ & $715.5 * * *$ & $795.0 * * *$ \\
\hline Supply level & 1 & $3.5^{\mathrm{ns}}$ & $0.0^{\mathrm{ns}}$ & $2.9^{\mathrm{ns}}$ & $42.3 * * *$ & $1.9^{\mathrm{ns}}$ & $29.7 * * *$ & $11.7 * *$ & $0.7^{\mathrm{ns}}$ \\
\hline Species & 3 & $1.4^{\mathrm{ns}}$ & $2.9 *$ & $37.2 * * *$ & $53.4 * * *$ & $59.8 * * *$ & $17.7 * * *$ & $11.9 * * *$ & $5.8 * *$ \\
\hline $\mathrm{N}: \mathrm{P} \times$ supply level & 4 & $2.3^{\mathrm{ns}}$ & $4.3 * *$ & $1.6^{\mathrm{ns}}$ & $0.9^{\mathrm{ns}}$ & $0.7^{\mathrm{ns}}$ & $0.3^{\mathrm{ns}}$ & $0.8^{\mathrm{ns}}$ & $1.1^{\mathrm{ns}}$ \\
\hline $\mathrm{N}: \mathrm{P} \times$ species & 12 & $1.0^{\mathrm{ns}}$ & $4.3 * * *$ & $0.8^{\mathrm{ns}}$ & $1.5^{\mathrm{ns}}$ & $2.4 *$ & $4.1 * * *$ & $3.8 * * *$ & $9.2 * * *$ \\
\hline Supply level $\times$ species & 3 & $1.0^{\mathrm{ns}}$ & $5.6 * *$ & $2.4^{\mathrm{ns}}$ & $2.9 *$ & $4.2 * *$ & $4.9 * *$ & $4.3 * *$ & $7.3 * * *$ \\
\hline $\mathrm{N}: \mathrm{P} \times$ level $\times$ species & 12 & $1.9^{\mathrm{ns}}$ & $3.0 * *$ & $0.7^{\mathrm{ns}}$ & $1.8^{\mathrm{ns}}$ & $1.0^{\mathrm{ns}}$ & $1.0^{\mathrm{ns}}$ & $0.6^{\mathrm{ns}}$ & $1.5^{\mathrm{ns}}$ \\
\hline
\end{tabular}

whereas the $\mathrm{P}$ concentration and $\mathrm{N}: \mathrm{P}$ ratio varied fiveto ten-fold (Figure 6e-1 and 7e-1). This difference is reflected by the differing $F$-values for the effects of
$\mathrm{N}: \mathrm{P}$ supply ratios in Table 6. The P concentration and $\mathrm{N}: \mathrm{P}$ ratio responded far more to the $\mathrm{N}: \mathrm{P}$ supply ratio than any of the morphological variables. 



\section{$\mathrm{N}: \mathrm{P}$ supply ratio}

Figure 5. Nutrient uptake by Carex plants after 13 weeks of growth in nutrient solutions with five different N:P supply ratios and two levels of overall nutrient supply (experiment 1$)$, given as the percentage $\mathrm{N}$ or $\mathrm{P}$ taken up from standard nutrient solutions $\left(6 \mathrm{mg} \mathrm{N} 1^{-1}, 0.34\right.$ mg $\mathrm{P}$ $\mathrm{1}^{-1}$ ) during $7 \mathrm{~h}$. Graphs (a) and (c) show means of the four species for each supply level; graphs (b) and (d) show means of the two supply levels for each species; error bars indicate $\pm 1 \mathrm{SE}$ of the means, as derived from three-way Anova.

Overall nutrient supply had little effect on the nutrient concentrations of shoots in experiment 1 and on the $\mathrm{N}: \mathrm{P}$ ratios of shoots and roots in both experiments. In contrast, the $\mathrm{N}$ and $\mathrm{P}$ concentrations of shoots in experiment 2 and the $\mathrm{N}$ and $\mathrm{P}$ concentrations of roots in both experiments differed by $20-45 \%$ between the high and low supply levels (Figure 6, Figure 7, Table 6 ). In experiment 2 , the $\mathrm{N}$ and $\mathrm{P}$ concentrations of plants grown at $5 \%$ daylight exceeded those of plants grown at $45 \%$ daylight. The difference between both light levels was particularly large for the P concentration of plants grown at high N:P supply ratios (Figure $6 e, g)$. Therefore, the N:P ratio of shoots and roots did not reach as high values at high $\mathrm{N}$ :P supply ratio with $5 \%$ daylight than with $45 \%$ daylight (Figure 7 i, $\mathrm{k})$.

Interspecific differences in tissue nutrient concentrations were always significant but of differing importance (Table 6). Relative to treatment effects, the $\mathrm{N}$ concentration tended to vary more among species than the $\mathrm{P}$ concentration and the $\mathrm{N}: \mathrm{P}$ ratio (Figure 6, Figure 7). In experiment $1, C$. curta generally had the highest and $C$. elata the lowest $\mathrm{N}$ and $\mathrm{P}$ concentrations. In experiment 2 , species ranked differently for $\mathrm{N}$ and $\mathrm{P}$ and for shoots and roots.

All species showed the same type of responses to the treatments (Figure 6, Figure 7). Nevertheless, species-by-treatment interactions were significant (Table 6) because the strength of the responses (plas- 

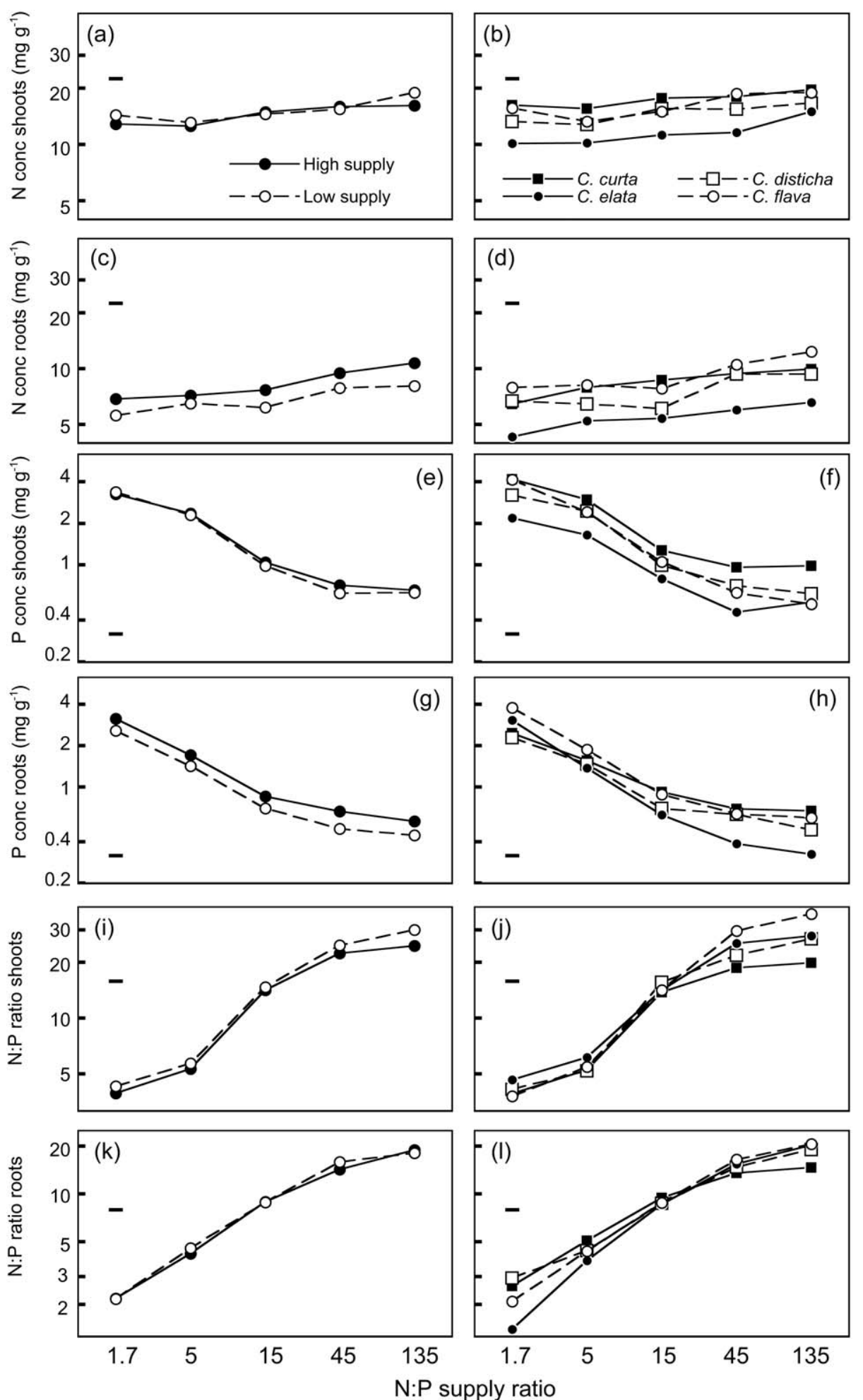

Figure 6. Concentrations of $\mathrm{N}$ and $\mathrm{P}$ as well as N:P ratio of shoots and roots (all on a log scale) of four Carex species after 13 weeks of growth in nutrient solutions with five different N:P supply ratios and two levels of overall nutrient supply (experiment 1). Graphs on the left side show means of the four species for each supply level; graphs on the right side show means of the two supply levels for each species; error bars (generally of negligible size) indicate $\pm 1 \mathrm{SE}$ of the means, as derived from three-way Anova. 



Figure 7. Concentrations of $\mathrm{N}$ and $\mathrm{P}$ as well as $\mathrm{N}: \mathrm{P}$ ratio of shoots and roots (all on a log scale) of four graminoid species after 12 weeks of growth in sand (experiment 2) at five N:P supply ratios, two light intensities (45\% or 5\% daylight) and three levels of overall nutrient supply $(\mathrm{H}=$ high, $\mathrm{M}=$ medium, $\mathrm{L}=$ low). Graphs on the left side show means of the four species for each light and supply level; graphs on the right side show means of the three supply levels at $45 \%$ daylight for each species; error bars (generally of negligible size) indicate $\pm 1 \mathrm{SE}$ of the means, as derived from three-way Anova. 
Table 7. Plasticity of the $\mathrm{N}$ and $\mathrm{P}$ concentrations of shoots in response to variation in the N:P supply ratio, level of nutrient supply and light intensity for each species in experiments 1 and 2. For both variables the mean across all treatments is given in the first column; plasticity (in $\%$ of the overall mean) is the relative difference between the highest and the lowest treatment mean for each of the three experimental factors.

\begin{tabular}{|c|c|c|c|c|c|c|c|c|}
\hline & \multicolumn{4}{|c|}{$\mathrm{N}$ concentration of shoots } & \multicolumn{4}{|c|}{$\mathrm{P}$ concentration of shoots } \\
\hline & $\begin{array}{l}\text { Mean (mg } \\
\left.\mathrm{g}^{-1}\right)\end{array}$ & $\mathrm{N}: \mathrm{P}$ ratio & $\begin{array}{l}\text { Supply } \\
\text { level }\end{array}$ & Light & $\begin{array}{l}\text { Mean (mg } \\
\left.\mathrm{g}^{-1}\right)\end{array}$ & $\mathrm{N}: \mathrm{P}$ ratio & $\begin{array}{l}\text { Supply } \\
\text { level }\end{array}$ & Light \\
\hline \multicolumn{9}{|l|}{ Experiment 1} \\
\hline Carex curta & 17.6 & 23.3 & 18.3 & & 1.69 & 186.1 & 12.0 & \\
\hline Carex disticha & 14.7 & 26.2 & 5.1 & & 1.21 & 201.2 & 19.1 & \\
\hline Carex elata & 11.3 & 42.5 & 3.0 & & 0.95 & 185.1 & 0.4 & \\
\hline Carex flava & 16.2 & 35.5 & 0.2 & & 1.26 & 282.1 & 11.9 & \\
\hline \multicolumn{9}{|l|}{ Experiment 2} \\
\hline Carex flava & 20.0 & 26.3 & 25.2 & 31.3 & 1.92 & 175.8 & 19.5 & 76.7 \\
\hline Carex panicea & 23.2 & 10.9 & 17.4 & 43.7 & 2.03 & 142.8 & 42.4 & 67.2 \\
\hline Molinia caerulea & 22.3 & 8.1 & 21.8 & 15.5 & 1.51 & 108.4 & 27.8 & 41.6 \\
\hline Phalaris arundinacea & 19.9 & 36.4 & 34.1 & 50.4 & 1.74 & 163.9 & 13.7 & 68.4 \\
\hline
\end{tabular}

ticity) varied among species. In experiment 1 , the interspecific differences in plasticity were not consistent: each species had the greatest plasticity for either $\mathrm{N}$ or $\mathrm{P}$ concentration and for either the N:P supply ratio or overall supply (Table 7 ). In experiment $2, P$. arundinacea had the most plastic shoot $\mathrm{N}$ concentration in response to all three experimental factors, whereas the $\mathrm{N}$ and $\mathrm{P}$ concentrations of $M$. caerulea were least plastic in response to $\mathrm{N}: \mathrm{P}$ supply ratios (Table 7, see also Figure 7b, f, j).

\section{Discussion}

This study combined two experiments using different plant species, different substrates (nutrient solutions vs. sand) and different light intensities (45\% vs. 5\% daylight). Some effects of N:P ratios occurred consistently, whereas others depended on species and growth conditions. To determine which effects of $\mathrm{N}: \mathrm{P}$ supply ratios are generally valid, it is useful to compare the patterns shown here with those from published experiments. As the design of nutrient treatments differed among studies, these comparisons do generally not take into account differences in overall supply level and should therefore be interpreted with some caution.

\section{Nutrient limitation of biomass production}

In both experiments, total biomass production depended significantly on both the $\mathrm{N}: \mathrm{P}$ ratio and the overall level of nutrient supply. The only exceptions were $C$. panicea and $M$. caerulea grown at $5 \%$ light intensity. The low biomass and the high nutrient concentrations of these species suggest that light limitation prevented them from responding to nutrient supply. With all other species, relationships between biomass and N:P supply ratios (Figure 2, Figure 3) were intermediate between those depicted in Figure 1a and Figure 1e: biomass either increased monotonically with increasing $\mathrm{N}: \mathrm{P}$ ratio (N-limitation) or reached a maximum at a N:P ratio of 15 or $45(\mathrm{~N}-$ limitation below this threshold and P-limitation above). The finding that growth was generally N-limited at a N:P ratio above 15 contrasts with the suggestion that the optimal N:P ratio for vascular plant growth is 10-15 (Duarte 1992; Koerselman and Meuleman 1996; Pegtel et al. 1996), but it concurs with the results of other growth experiments, which all found $\mathrm{N}$ limitation at N:P supply ratios higher than 15 (Veerkamp et al. 1980; Shaver and Melillo 1984; Thornton 1991; Ryser and Lambers 1995; Romero et al. 1999).

Various reasons may cause the $\mathrm{N}: \mathrm{P}$ ratio separating $\mathrm{N}$ from $\mathrm{P}$ limitation to be higher in growth experiments than in the field. First, all $\mathrm{N}$ and $\mathrm{P}$ supplied in the experiments could be taken up directly by plants. No phosphate was fixed by the quartz sand used in experiment 2 within two days (S. Güsewell, unpublished data), and the uptake experiments showed that most $\mathrm{P}$ was taken up after $7 \mathrm{~h}$ plants roots (Figure $5 \mathrm{c}, \mathrm{d}$ ). In the field, $\mathrm{P}$ is often acquired with the help of root exudations or mycorrhizal associa- 
tions (Kroehler and Linkins 1988; Schachtman et al. 1998; Koide and Kabir 2000; Treseder and Vitousek 2001). These mechanisms entail costs in terms of carbon and nitrogen (Ratnayke et al. 1978; Clarkson 1985). Fertilisation with $P$ in the field increases the fraction of total soil $\mathrm{P}$ that is dissolved in the soil solution (Kovar and Barber 1988), enabling plants to acquire their phosphorus at lower costs (Caldwell et al. 1992). In this way, fertilisation with $P$ may even enhance the biomass production of plants that are in short supply of $\mathrm{N}$.

The occurrence of $\mathrm{N}$ limitation at high N:P supply ratios may also be particular to short-term growth experiments with young plants. Wetland plants, especially graminoids, can take advantage of high $\mathrm{N}$ supply even when $\mathrm{P}$ is scarce by producing biomass with a low $\mathrm{P}$ concentration and through the translocation of $\mathrm{P}$ from old to young plants parts (Veerkamp et al. 1980; Jonasson and Chapin 1985; Perez-Corona and Verhoeven 1996). However, this may lead to reduced growth subsequently (Güsewell et al. 2003; Limpens et al. 2003). In addition, young plants have to take up all nutrients used for growth from the environment, whereas older plants partly use nutrients which they stored previously (e.g. Jonasson and Chapin 1985; Pfadenhauer and Lütke-Twenhöven 1986; Bernard et al. 1988). The ability of plants to recycle $\mathrm{N}$ and $\mathrm{P}$ differs: only $50-60 \%$ of $\mathrm{N}$, but as much as $80-90 \%$ of $\mathrm{P}$ can be resorbed from the above-ground biomass (Aerts and Chapin 2000). Graminoids are particularly efficient in resorbing $\mathrm{P}$ (Aerts 1996; Aerts et al. 1999), which may cause the biomass N:P ratio of older plants to be lower than the $\mathrm{N}: \mathrm{P}$ supply ratio. The effects of N:P supply ratios on nutrient storage and on long-term performance need further investigation to fully understand why the optimal N:P ratios seem to differ between short-term and long-term growth.

\section{Biomass allocation and morthology}

The root mass ratio (RMR) generally decreased with increasing N:P ratio and with increasing overall nutrient supply; this indicates that it was primarily determined (i.e. reduced) by the supply of $\mathrm{N}$, as proposed by Lambers et al. (1998). A similar pattern of response was found by Ryser and Lambers (1995) and Shaver and Melillo (1984). In all these cases N was more limiting for plant growth than $\mathrm{P}$, so the RMR was primarily determined by the supply of the limiting nutrient. This would be consistent with the model that the RMR is controlled by the ability of shoots to act as sinks for assimilates (Wilson 1988). However, there are also counter-examples: Perez-Corona and Verhoeven (1999) found that P supply did not or did only weakly, influence the RMR of $C$. $d i$ andra, C. rostrata and C. acutiformis even though it had a considerable effect on their biomass production. Conversely, a ten-fold difference in P supply caused an almost two-fold difference in the RMR of two wheat cultivars, although their biomass production was hardly affected (Horst et al. 1996). In experiment 1 of this study, the RMR of $C$. elata decreased less with increasing $\mathrm{N}: \mathrm{P}$ supply ratio than that of $C$. curta and $C$. flava, yet their biomass responded similarly. The RMR can also respond differently to $\mathrm{N}$ supply according to the growth medium, amount and form of $\mathrm{N}$ used (Crabtree and Bazzaz 1993; Leith et al. 1999). In conclusion, none of the simple control mechanisms suggested in Figure 1 seems to apply generally for the RMR.

Leaf morphology (dry matter content and SLA) was much more affected by light intensity than by nutrient supply, as is generally the case (e.g. Peace and Grubb 1982; Olff 1992). At 45\% light (but not at $5 \%$ light) leaf dry matter content increased and SLA decreased with increasing N:P supply ratio; there was basically no effect of overall nutrient supply (as in Figure 1c). These responses were surprising for two reasons: First, SLA is normally positively correlated with the growth rate across nutrient levels (Poorter and Nagel 2000). As biomass tended to increase with increasing N:P supply ratio, an increase rather than a decrease in SLA might have been expected. Second, dry matter content is generally positively correlated, and SLA negatively correlated with the life span of biomass (but see Diemer et al. 1992; Ryser 1996; Schläpfer and Ryser 1996; Reich et al. 1999; Ryser and Urbas 2000). Increasing dry matter content of leaves would therefore suggest that their life span should be higher at high N:P supply ratios, but the opposite was suggested by growth experiments with wetland plants and by field experiments (Bollens 2000; Gordon et al. 2001; Tomassen et al. 2003).

The responses of leaf morphology to N:P ratios also differed in other experiments. Ryser and Lambers (1995) found the SLA of Dactylis glomerata to be independent of the N:P supply ratio and that of Brachypodium pinnatum to increase with increasing $\mathrm{N}: \mathrm{P}$ supply ratio. The results of some studies varying the supply of P concur with my results (Ryser et al. 1997; Perez-Corona and Verhoeven 1999), but studies vary- 
ing the supply of $\mathrm{N}$ yielded inconsistent results (Fichtner and Schulze 1992; Garnier and Freijsen 1994). There seems to be no consistent pattern in the effects of N:P ratios on leaf morphology, as there are no consistent patterns in the effects of nutrient supply in general (Dijkstra 1989).

\section{Nutrient uptake and concentrations in biomass}

Nitrogen and phosphorus concentrations in plant biomass were related to the $\mathrm{N}: \mathrm{P}$ supply ratio in opposite ways. The tissue $\mathrm{N}$ concentration was also less plastic in response to the $\mathrm{N}: \mathrm{P}$ supply ratio than the $\mathrm{P}$ concentration. In both experiments, the $\mathrm{N}$ concentration varied more among species than among treatments, whereas the $\mathrm{P}$ concentration (and the N:P ratio) varied more among treatments. The effect of overall nutrient supply on the $\mathrm{N}$ concentration was sometimes stronger than that of the N:P supply ratio, whereas the $\mathrm{P}$ concentration always depended mostly on the N:P supply ratio. All these differences between $\mathrm{N}$ and $\mathrm{P}$ have been found more generally in field and greenhouse experiments (Güsewell and Koerselman 2002). Even the large variation in $\mathrm{P}$ concentrations found here is not exceptional, as six-fold variation in $\mathrm{P}$ concentration was found between unfertilised and P-fertilised plots in field experiments (Kielland and Chapin 1994), and up to ten-fold variation in other growth experiments (Veerkamp et al. 1980).

The contrasting patterns of variation in $\mathrm{N}$ and $\mathrm{P}$ concentrations suggest that $\mathrm{N}$ uptake is mainly regulated by demand (Imsande and Touraine 1994), while P uptake depends more on availability (Kielland and Chapin 1994; Schachtman et al. 1998). The uptake trial carried out at the end of experiment 1 also illustrates this difference: P-limited plants (grown at N:P supply ratios of 45 or 135) hardly took up any nitrate, whereas N-limited plants (grown at a N:P supply ratio of 5) took up a large part of the phosphate within $7 \mathrm{~h}$, although their demand for P must have been low. The uptake of $\mathrm{P}$ was only reduced in plants grown at a N:P supply ratio of 1.7 , probably to prevent a toxic accumulation of $\mathrm{P}$ when its supply was excessive. This type of relationship between N:P supply ratios and nutrient uptake from a standard solution is typical and has even been used as an indicator of nutrient availability for algae (Suttle and Harrison 1988 and references therein). The dependence of the relative uptake rates of $\mathrm{N}$ and $\mathrm{P}$ on the $\mathrm{N}: \mathrm{P}$ supply ratio was mostly independent of overall nutrient supply during growth. The lower uptake of $\mathrm{N}$ from plants with low
$\mathrm{N}: \mathrm{P}$ ratio grown at the low supply level (Figure 5a) might have been due to the small size of their root systems, rather than low root activity, as solutions in beakers were not constantly mixed during the uptake trial.

\section{Interspecific differences}

The four species within each experiment varied twoto three-fold in average biomass production; species that normally occur at the more productive sites $(C$. elata, C. disticha, $P$. arundinacea) had the greater biomass, as found in many other short-term experiments (Fichtner and Schulze 1992; Elberse and Berendse 1993; Ryser 1996; Ryser and Urbas 2000). In more longterm experiments these rankings may disappear or turn into the reverse (Elberse and Berendse 1993; Ryser 1996).

In both experiments, the taller species generally had lower $\mathrm{N}$ and $\mathrm{P}$ concentrations in their shoots than the smaller species, indicating that a more productive use of these nutrients allowed the greater biomass production (Garnier et al. 1995; Garnier and Aronson 1998). The $P$ concentrations of shoots hardly differed among species in experiment 2, perhaps because growth was mainly limited by $\mathrm{N}$. The $\mathrm{N}$ and $\mathrm{P}$ concentrations of roots were unrelated to the biomass of the species, especially when these nutrients were not limiting (at high $\mathrm{N}: \mathrm{P}$ supply ratio for $\mathrm{N}$ and low $\mathrm{N}: \mathrm{P}$ supply ratio for $\mathrm{P}$ ), suggesting that differences in these concentrations reflected different degrees of nutrient accumulation and not of nutrient productivity (chapin 1980; Chapin et al. 1990).

The responses of the seven species to nutrient treatments were qualitatively similar. This may be due to the fact that all were graminoids. In particular, the genus Carex is physiologically quite homogeneous (Choo and Albert 1999a,b; Visser et al. 2000). The responses might have differed more among species if other growth forms, e.g. forbs or shrubs, had also been studied (Lechowicz and Shaver 1982; Eckstein and Karlsson 1997; Falkengren-Grerup 1988; Aerts et al. 1999).

Despite qualitatively similar responses to treatments, the species differed in plasticity. However, they could not be ranked from the most to the least plastic, as this depended on the trait and on the experimental factor for which plasticity was quantified. This may be because the evolutionary implications of phenotypic plasticity depend on whether the adjustments are 'inevitable' (reflecting resource shortage) or 
'adaptive' (partly compensating for this shortage): high 'inevitable' plasticity may be the result of low 'adaptive' plasticity (Sultan 1995; Ryser and Eek 2000). In experiment 2 , the biomass production of $M$. caerulea was most severely reduced at the high $\mathrm{N}: \mathrm{P}$ ratios ('inevitable'), possibly because its RMR did not decrease ('adaptive').

Functional relationships between plant traits also depend on the range of environmental conditions for which these relationships are determined. For example, RMR and SLA are negatively correlated with growth rates across light levels but positively across nutrient levels (Poorter and Nagel 2000). The low plasticity in RMR of $M$. caerulea in experiment 2 may have caused this species to respond strongly to light but weakly to nutrients (cf. Sultan 2001).

Finally, the average effects of the experimental factors on plant traits differed, and this may have influenced how species ranked in plasticity. Biomass and RMR were affected to a similar degree by N:P supply ratios and overall nutrient supply, and the most plastic species were essentially the same for both factors (Table 5). By contrast, the shoot $\mathrm{N}$ concentration in experiment 1 and the shoot $\mathrm{P}$ concentration in both experiments depended far more on the N:P supply ratio than on overall nutrient supply. Here the species with greatest plasticity differed for each factor (Table 7), but this cannot be taken as evidence that the species-specific responses to $\mathrm{N}: \mathrm{P}$ supply ratios and those to overall nutrient supply were determined by different mechanisms. The same difficulty also occurs when the responses to $\mathrm{N}$ and to $\mathrm{P}$ are compared. For example, Keddy et al. (2001) found no correlation between the growth responses of 21 wetland species to a low supply of $\mathrm{N}$ their responses to a low supply of $\mathrm{P}$, possibly because $\mathrm{N}$ was more limiting for growth than $\mathrm{P}$.

Contrary to expectation, the growth responses of M. caerulea and $P$. arundinacea to $\mathrm{N}: \mathrm{P}$ supply ratios did not reflect their contrasting $\mathrm{N}: \mathrm{P}$ ratios in the field. M. caerulea, which mainly dominates at P-limited field sites, even performed worse at high N:P supply ratios than $P$. arundinacea and the Carex species. There were also no inherent differences in $\mathrm{P}$ concentrations between $M$. caerulea and $P$. arundinacea that would have suggested different physiological requirements or a different ability to compete for $\mathrm{P}$ according to Tilman's resource ratio model (Tilman 1982; Mamolos et al. 1995; Tilman 1997; Tilman et al. 1999). However, M. caerulea had a greater biomass allocation to roots at high $\mathrm{N}: \mathrm{P}$ ratios (Figure $3 \mathrm{~d}$ ), and its leaf turnover increased less as $\mathrm{P}$ became limiting (S. Güsewell, unpublished data). This might reduce nutrient losses and provide $S$. caerulea a competitive advantage in the long-term under P-limited conditions (El-Kahloun et al. 2000).

\section{Conclusions}

This study has shown that new insights into the effects of nutrient supply on plant growth and nutrient use can be gained by varying $\mathrm{N}: \mathrm{P}$ supply ratios at different levels of overall nutrient supply. The results have shown that plant traits depend on the N:P supply ratio to a different extent. Some traits (tissue $\mathrm{P}$ concentration and $\mathrm{N}: \mathrm{P}$ ratio, rates of $\mathrm{N}$ and $\mathrm{P}$ uptake) were almost entirely determined by the $\mathrm{N}: \mathrm{P}$ supply ratio; they showed little or no dependence on overall nutrient supply and rather small interspecific variation, and these effects were consistent with those of published studies. Other traits (tissue $\mathrm{N}$ concentration, root mass ratio, leaf dry matter content and specific leaf area) were only weakly related to the $\mathrm{N}: \mathrm{P}$ supply ratio; they depended more on overall supply or on light intensity and varied strongly among plant species; treatment effects on these traits often varied among published studies. In general, physiological traits showed a stronger dependence on $\mathrm{N}: \mathrm{P}$ supply ratios than morphological traits, but this was not true in all cases. The seven species responded in a similar way to nutrient supply in this study despite their different responses to nutrient availability in the field. This may be due to the short duration of the experiments, and it will therefore be necessary to investigate how $\mathrm{N}: \mathrm{P}$ supply ratios affect plant growth in the long term to understand what determines a species' ability to occur in $\mathrm{N}$ - or P-limited wetlands.

\section{Acknowledgements}

Ursula Bollens, T. Fotsch, R. Gessler, A. Hegi, A. Hoenderboom, S. Locher and J. van Rhenen helped with the experimental work. Their valuable assistance is gratefully acknowledged. W. Koerselman, E. Weber and two referees commented helpfully on drafts of the manuscript. The research was partly funded by the Swiss Federal Office of Environment, Forest and Landscape and partly by grand ENV4-CT97-5075 from the Commission of the European Communities. 


\section{References}

Aerts R. 1996. Nutrient resorption from senescing leaves of perennials: are there general patterns? Journal of Ecology 84: 597608.

Aerts R. and Chapin F.S. III 2000. The mineral nutrition of wild plants revisited: a re-evaluation of processes and patterns. Advances in Ecological Research 30: 1-67.

Aerts R., Verhoeven J.T.A. and Whigham D.F. 1999. Plant-mediated controls on nutrient cycling in temperate fens and bogs. Ecology 80: 2170-2181.

Anuradha M. and Narayanan A. 1991. Promotion of root elongation by phosphorus deficiency. Plant and Soil 136: 273-275.

Bausenwein U., Millard P. and Raven J.A. 2001. Remobilized oldleaf nitrogen predominates for spring growth in two temperate grasses. New Phytologist 152: 283-290.

Bernard J.M., Solander D. and Kvet J. 1988. Production and nutrient dynamics in Carex wetlands. Aquatic Botany 39: 125-147.

Bobbink R., Hornung M. and Roelofs J.G.M. 1988. The effects of air-borne nitrogen pollutants on species diversity in natural and semi-natural European vegetation - a review. Journal of Ecology $86: 717-738$.

Bollens U. 2000. Effects of nutrient inputs and water regime on wetland vegetation and the performance of wetland species. $\mathrm{Ph.D}$. thesis 13560, Swiss Federal Institute of Technology, Zürich, Switzerland.

Caldwell M.M. Dudley L.M. and Lilieholm B. 1992. Soil solution phosphate, root uptake kinetics and nutrient acquisition: implications for a patchy soil environment. Oecologia 89: 305-309.

Chapin F.S. 1980. The mineral nutrition of wild plants. Annual Reviews of Ecology and Systematics 11: 233-260.

Chapin F.S. III, Schulze E.D. and Mooney H.A. 1990. The ecology and economics of storage in plants. Annual Reviews of Ecology and Systematics 21: 423-447.

Choo Y.- S. and Albert R. 1999a. Mineral ion, nitrogen and organic solute pattern in sedges (Carex spp.) - a contribution to the physiotype concept. I. Field samples. Flora 194: 59-74.

Choo Y.- S. and Albert R. 1999b. Mineral ion, nitrogen and organic solute pattern in sedges (Carex spp.) - a contribution to the physiotype concept. II. Culture experiments. Flora 194: 75-87.

Clarkson D.T. 1985. Factors affecting mineral nutrient acquisition by plants. Annual Reviews of Plant Physiology 36: 77-115.

Crabtree R.C. and Bazzaz F.A. 1993. Seedling response of four birch species to simulated nitrogen deposition: ammonium vs. nitrate. Ecological Applications 3: 315-321.

de Kroon H. and Bobbink R. 1997. Clonal plant dominance under elevated nitrogen deposition, with special reference to Brachypodium pinnatum in chalk grassland. Pages 359-379. In: H. De Koon, and J. Van Groenendael (eds), The ecology and evolution of clonal plants. Backhuys Publishers, Leiden, The Netherlands.

Diemer M., Körner C. and Prock S. 1992. Leaf life span in wild perennial herbaceous plants: A survey and attempts at a functional interpretation. Oecologia 89: 10-16.

Dijkstra P. 1989. Cause and effect of differences in specific leaf area. Pages 125-140. In: H. Lambers, M.L. Cambridge, H. Konings and T.L. Pons (eds), Causes and consequences of variation in growth rate and productivity of higher plants. SPB Academic Publishing, The Hague, The Netherlands.

Duarte C.M. 1992. Nutrient concentrations of aquatic plants: patterns across species. Limnology and Oceanography 37: 882-889.
Eckstein R.L. and Karlsson P.S. 1997. Above-ground growth and nutrient use by plants in a subarctic environment: effects of habitat, life-form and species. Oikos 79: 311-324.

Eckstein R.L., Karlsson P.S. and Weih M. 1999. Leaf life span and nutrient resorption as determinants of plant nutrient conservation in temperate-arctic regions. New Phytologist 143: 177-189.

El-Kahloun M., Boeye D., Verhagen B. and van Haesebroeck V. 2000. A comparison of the nutrient status of Molinia caerulea and neighbouring vegetation in a rich fen. Belgian Journal of Botany 133: 91-102.

Elberse W.T.H. and Berendse F. 1993. A comparative study of the growth and morphology of eight grass species from habitats with different nutrient availabilities. Functional Ecology 7: 223-229.

Ellenberg H. 1996. Vegetation Mitteleuropas mit den Alpen 5. Aufl. Eugen Ulmer, Stuttgart.

Ellenberg H., Weber H.E., Düll R., Wirth V., Werner W. and Paulissen D. 1991. Zeigerwerte von Pflanzen in Mitteleuropa. Scripta Geobotanica 18: 1-248.

Ericsson T. 1995. Growth and shoot:root ratio of seedlings in relation to nutrient availability. Plant and Soil 168-169: 205-214.

Falkengren-Grerup U. 1998. Nitrogen response of herbs and graminoids in experiments with simulated acid soil solution. Environmental Pollution 102(S1): 93-99.

Fichtner K. and Schulze E.-D. 1992. The effect of nitrogen nutrition on growth and biomass partitioning of annual plants originating from habitats of different nitrogen availability. Oecologia 92: 236-241.

Flückiger W. and Braun S. 1998. Nitrogen deposition in Swiss forests and its possible relevance for leaf nutrient status, parasite attacks and soil acidification. Environmental Pollution 102(S1): 69-76.

Garnier E. 1998. Interspecific variation in plasticity of grasses in response to nitrogen supply. Pages 155-181. In: G.P. Cheplick (ed), Population Biology of Grasses. Cambridge University Press, Cambridge, UK.

Garnier E. and Aronson J. 1998. Nitrogen-use efficiency from leaf to stand level: clarifying the concept. Pages 515-538. In: H. Lambers, H. Poorter and M.M.I. van Vuuren (eds), Interent variation in plant growth. Physiological mechanisms and ecological consequences. Backhuys Publishers, Leiden, The Netherlands.

Garnier E. and Freijsen A.H.J. 1994. On ecological inference from laboratory experiments conducted under optimum conditions. Pages 267-294. In: J. Roy and E. Garnier (eds), A whole plant perspective on carbon-nitrogen interactions. SPB Academic Publishing, The Hague, The Netherlands.

Garnier E., Gobin O. and Poorter H. 1995. Nitrogen productivity depends on photosynthetic nitrogen use efficiency and on nitrogen allocation within the plant. Annals of Botany 76: 667-672.

Gordon C., Wynn J.M. and Woodin S.J. 2001. Impacts of increased nitrogen supply on high Arctic heath: the importance of bryophytes and phosphorus availability. New Phytologist 149: 461471.

Güsewell S., Bollens U., Ryser P. and Klötzli F. 2003. Contrasting effects of nitrogen, phosphorus and water regime on first-year and second-year growth of 16 wetland plant species. Functional Ecology 11: 754-765.

Güsewell S. and Koerselman W. 2002. Variation in nitrogen and phosphorus concentrations of wetland plants. Perspectives in Ecology, Evolution and Systematics 5: 37-61. 
Hirose T. and Bazzaz F.A. 1998. Trade-off between light and nitrogen-use efficiency in canopy photosynthesis. Annals of Botany 82: 195-202.

Horst W.J., Abdou M. and Wiesler F. 1996. Differences between wheat cultivars in acquisition and utilization of phosphorus. Zeitschrift für Pflanzenernährung und Bodenkunde 159: 155161.

Imsande J. and Touraine B. 1994. N demand and the regulation of nitrate uptake. Plant Physiology 105: 3-7.

Ingestad T. and Agren G.I. 1991. The influence of plant nutrition on biomass allocation. Ecological Applications 1: 168-174.

Jonasson S. and Chapin F.S. III. 1985. Significance of sequential leaf development for nutrient balance of the cotton sedge Eriophorum vaginatum L. Oecologia 67: 511-518.

Keddy P., Fraser L.H. and Keogh T.A. 2001. Responses of 21 wetland species to shortages of light, nitrogen and phosphorus. Bulletin of the Geobotanical Institute ETH 67: 13-26.

Kielland K. and Chapin F.S. III. 1994. Phosphate uptake in arctic plants in relation to phosphate supply: the role of spatial and temporal variability. Oikos 70: 443-448.

Kirkham F.W. 2001. Nitrogen uptake and nutrient limitation in six hill moorland species in relation to atmospheric nitrogen deposition in England and Wales. Journal of Ecology 89: 1041-1053.

Koerselman W. and Meuleman A.F.M. 1996. The vegetation N:P ratio: a new tool to detect the nature of nutrient limitation. Journal of Applied Ecology 33: 1441-1450.

Koide R.T. and Kabir Z. 2000. Extraradical hyphae of the mycorrhizal fungus Glomus intraradices can hydrolyse organic phosphate. New Phytologist 148: 511-517.

Kovar J.L. and Barber S.A. 1988. Phosphorus supply characteristics of 33 soils as influenced by seven rates of phosphorus addition. Soil Science Society of America Journal 52: 160-165.

Kroehler C.J. and Linkins A.E. 1988. The root surface phosphatases of Eriophorum vaginatum: Effects of temperature, $\mathrm{pH}$, substrate concentration and inorganic phosphorus. Plant and Soil 105: 3-10.

Lambers H. Chapin III F.S. and Pons T.L. 1988. Plant Physiological Ecology. Springer, New York, USA.

Lauber K. and Wagner G. 1996. Flora Helvetica. Paul Haupt, Bern, Switzerland.

Lechowicz M.J. and Shaver G.R. 1982. A multivariate approach to the analysis of factorial fertilization experiments in Alaskan arctic tundra. Ecology 63: 1029-1038.

Leith I.D., Hicks W.K., Fowler D. and Woodin S.J. 1999. Differential responses of UK upland plants to nitrogen deposition. New Phytologist 141: 277-289.

Limpens J., Berendse F. and Klees H. 2003. N deposition affects N availability in interstitial water, growth of Sphagnum and invasion of vascular plants in bog vegetation. New Phytologist 157: 339-347.

Lipson D. and Näsholm T. 2001. The unexpected versatility of plants: organic nitrogen use and availability in terrestrial ecosystems. Oecologia 128: 305-316.

Mamolos A.P., Veresoglou D.S. and Barbayiannis N. 1995. Plant species abundance and tissue concentrations of limiting nutrients in low-nutrient grasslands: a test of competition theory. Journal of Ecology 83: 485-495.

Northup R.R., Daglgren R.A. and McColl J.G.1988. Polyphenols as regulators of plant-litter-soil interactions in northern California's pygmy forest: a positive feedback? Biogeochemistry 42 : 189-220.
Olff H. 1992. Effects of light and nutrient availability on dry matter and $\mathrm{N}$ allocation in six successional grassland species: Testing for resource ratio effects. Oecologia 89: 412-421.

Peace W.J.H. and Grubb P.J. 1982. Interaction of light and mineral nutrient supply in the growth of Impatiens parviflora. New Phytologist 90: 127-150.

Pegtel D.M., Bakker J.P., Verweij G.L. and Fresco L.F.M. 1996. N, $\mathrm{K}$ and $\mathrm{P}$ deficiency in chronosequential cut summer-dry grasslands on gley podzol after cessation of fertilizer application. Plant and Soil 178: 121-131.

Perez-corona M.E. and Verhoeven J.T.A. 1996. Effects of soil P status on growth and $\mathrm{P}$ and $\mathrm{N}$ uptake of Carex species from fens differing in P-availability. Acta Botanica Neerlandica 45: 381392.

Perez-Corona M.E. and Verhoeven J.T.A. 1999. Biomass allocation and phosphorus productivity of Carex species in relation to soil phosphorus status. Israel Journal of Plant Sciences 47: 97-102.

Pfadenhauer J. and Lütke-Twenhöven F. 1986. Nährstoffökologie von Molinia coerulea und Carex acutiformis auf baumfreien Niedermooren des Alpenvorlandes. Flora 178: 257-166.

Poorter H. and Nagel O. 2000. The role of biomass allocation in the growth response of plants to different levels of light, $\mathrm{CO}_{2}$, nutrients and water: a quantitative review. Australian Journal of Plant Physiology 27: 595-607.

Ratnayke M., Leonard R.T. and Menge J.A. 1978. Root exudation in relation to supply of phosphorus and its possible relevance to mycorrhizal formation. New Phytologist 81: 543-552.

Reich P.B., Ellsworth D.S., Walters M.B., Vose J.M., Gresham C., Volin J.C. and Bowman W.D. 1999. Generality of leaf trait relationships: a test across six biomes. Ecology 80: 1955-1969.

Reynolds H.L. and D'Antonio C. 1996. The ecological significance of plasticity in root weight ratio in response to nitrogen: Opinion. Plant and Soil 185: 75-97.

Robinson D. and Rorison I.H. 1988. Plasticity in grass species in relation to nitrogen supply. Functional Ecology 2: 249-257.

Roem W.J. and Berendse F. 2000. Soil acidity and nutrient supply ratio as possible factors determining changes in plant species diversity in grassland and heathland communities. Biological Conservation 92: 151-161.

Roem W.J., Klees H. and Berendse F. 2002. Effects of nutrient addition and acidification on plant species diversity and seed germination in heathland. Journal of Applied Ecology 39: 937-948.

Romero J.A., Brix H. and Comin F.A. 1999. Interactive effects of $\mathrm{N}$ and $\mathrm{P}$ on growth, nutrient allocation and $\mathrm{NH}_{4}$ uptake kinetics by Phragmites australis. Aquatic Botany 64: 369-380.

Ryser P. 1996. The importance of tissue density for growth and life span of leaves and roots: a comparison of five ecologically contrasting grasses. Functional Ecology 10: 717-723.

Ryser P. and Eek L. 2000. Consequences of phenotypic plasticity vs. interspecific differences in leaf and root traits for acquisition of aboveground and belowground resources. American Journal of Botany 87: 402-411.

Ryser P. and Lambers H. 1995. Root and leaf attributes accounting for the performance of fast- and slow-growing grasses at different nutrient supply. Plant and Soil 170: 251-265.

Ryser P. and Urbas P. 2000. Ecological significance of leaf life span among Central European grass species. Oikos 91: 41-50.

Ryser P., Verduyn B. and Lambers H. 1997. Phosphorus allocation and utilization in three grass species with contrasting response to N and P supply. New Phytologist 137: 293-302. 
Schachtman D.P., Reid R.J. and Ayling S.M. 1998. Phosphorus uptake by plants: from soil to cell. Plant Physiology 116: 447-453.

Schieving F. and Poorter H. 1999. Carbon gain in a multispecies canopy: the role of specific leaf area and photosynthetic nitrogen-use efficiency in the tragedy of the commons. New Phytologist 143: 201-211.

Schläpfer B. and Ryser P. 1996. Leaf and root turnover of three ecologically contrasting grass species in relation to their performance along a productivity gradient. Oikos 75: 398-406.

Shaver G.R. and Melillo J.M. 1984. Nutrient budgets of marsh plants: efficiency concepts and relation to availability. Ecology 65: 1491-1510.

Sultan S.E. 1995. Phenotypic plasticity and plant adaptation. Acta Botanica Neerlandica 44: 363-383.

Sultan S.E. 2001. Phenotypic plasticity for fitness components in Polygonum species of contrasting ecological breadth. Ecology 82: $328-343$

Suttle C.A. and Harrison P.J. 1988. Ammonium and phosphate uptake rates, $\mathrm{N}: \mathrm{P}$ supply ratios and evidence of $\mathrm{N}$ and $\mathrm{P}$ limitation in some oligotrophic lakes. Limnology and Oceanography 32: $186-202$.

Thornton B. 1991. Effect of nutrition on the short-term response of Molinia caerulea to defoliation. Annals of Botany 68: 569-576.

Tilman D. 1982. Resource competition and community structure. Princeton University Press, Princeton, UK.

Tilman D. 1997. Mechanisms of plant competition. Pages 239-261. In: M.J. Crawley (ed), Plant Ecology, 2nd Edition. Blackwell Science, Oxford, UK.

Tilman D. and Wedin D. 1991. Plant traits and resource reduction for five grasses growing on a nitrogen gradient. Ecology 72 : 685-700.

Tilman E.A., Tilman D., Crawley M.J. and Johnston A.E. 1999. Biological weed control via nutrient competition: potassium limitation of dandelions. Ecological Applications 9: 103-111.
Tomassen H.B.M., Smolders A.J.P., Lamers L.P.M. and Roelofs J.G.M. 2003. Stimulated growth of Betula pubescens and Molinia caerulea on ombrotrophic bogs: role of high levels of atmospheric deposition. Journal of Ecology 91: 357-370.

Treseder K.K. and Vitousek P.M. 2001. Effects of soil nutrient availability on investment in acquisition of $\mathrm{N}$ and $\mathrm{P}$ in Hawaiian rain forests. Ecology 82: 946-954.

Tuomi J. Kytöviita M.- M. and Härdling R. 2001. Cost efficiency of nutrient acquisition and the advantage of mycorrhizal symbiosis for the host plant. Oikos 92: 62-70.

Veerkamp M.T., Corré W.J., Atwell B.J. and Kuiper P.J.C. 1980. Growth rate and phosphate utilization of some Carex species from a range of oligotrophic to eutrophic swamp habitats. Physiologia Plantarum 50: 237-240.

Verhoeven J.T.A., Beltman B. and de Caluwe H. 1996. Changes in plant biomass in fens in the Vechtplassen area, as related to nutrient enrichment. Netherlands Journal of Aquatic Ecology 30: 227-237.

Visser E.J.W., Bögemann G.M., van de Steeg H.M., Pierik R. and Blom C.W.P.M. 2000. Flooding tolerance of Carex species in relation to field distribution and aerenchyma formation. New Phytologist 148: 93-103.

Willby N.J., Pulford I.D. and Flowers T.H. 2001. Tissue nutrient signatures predict herbaceous-wetland community responses to nutrient availability. New Phytologist 152: 463-481.

Wilson J.B. 1988. A review of evidence on the control of shoot: root ratio, in relation to models. Annals of Botany 61: 433-449.

Woo I. and Zedler J.B. 2002. Can nutrients alone shift a sedge meadow towards dominance by the invasive Typha $\times$ glauca? Wetlands 22: 509-521. 